\title{
EBR-II Primary Tank Wash-Water Alternatives Evaluation
}

\author{
R. L. Demmer \\ J. B. Heintzelman
}

L. N. Squires

R. H. Meservey

May 2008

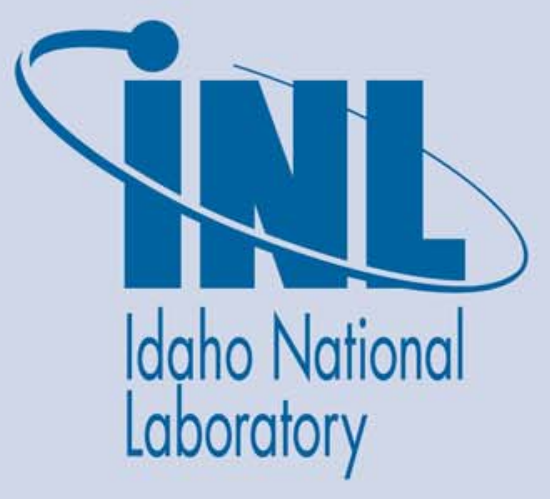




\title{
EBR-II Primary Tank Wash-Water Alternatives Evaluation
}

\author{
R. L. Demmer \\ J. B. Heintzelman \\ L. N. Squires \\ R. A. Meservey \\ May 2008

\begin{abstract}
Idaho National Laboratory
Idaho Falls, Idaho 83415
\end{abstract} \\ Prepared for the \\ U.S. Department of Energy \\ Assistant Secretary for Environmental Management \\ Under DOE Idaho Operations Office \\ Contract DE-AC07-05ID14517
}




\section{ABSTRACT}

The EBR-II reactor at Idaho National Laboratory was a liquid sodium metal cooled reactor that operated for 30 years. It was shut down in 1994; the fuel was removed by 1996; and the bulk of sodium metal coolant was removed from the reactor by 2001 . Approximately $1100 \mathrm{~kg}$ of residual sodium remained in the primary system after draining the bulk sodium. To stabilize the remaining sodium, both the primary and secondary systems were treated with a purge of moist carbon dioxide. Most of the residual sodium reacted with the carbon dioxide and water vapor to form a passivation layer of primarily sodium bicarbonate. The passivation treatment was stopped in 2005 and the primary system is maintained under a blanket of dry carbon dioxide. Approximately $670 \mathrm{~kg}$ of sodium metal remains in the primary system in locations that were inaccessible to passivation treatment or in pools of sodium that were too deep for complete penetration of the passivation treatment.

The EBR-II reactor was permitted by the Idaho Department of Environmental Quality (DEQ) in 2002 under a RCRA permit that requires removal of all remaining sodium in the primary and secondary systems by 2022 . The proposed baseline closure method would remove the large components from the primary tank, fill the primary system with water, react the remaining sodium with the water and dissolve the reaction products in the wash water. This method would generate a minimum of 100,000 gallons of caustic, liquid, low level radioactive, hazardous waste water that must be disposed of in a permitted facility.

On February 19-20, 2008, a workshop was held in Idaho Falls, Idaho, to look at alternatives that could meet the RCRA permit clean closure requirements and minimize the quantity of hazardous waste generated by the cleanup process. The workshop convened a panel of national and international sodium cleanup specialists, subject matter experts from the INL, and the EBR-II Wash Water Project team that organized the workshop. The workshop was conducted by a trained facilitator using Value Engineering techniques to elicit the most technically sound solutions from the workshop participants.

A brainstorming session was held to identify possible alternative treatment methods that would meet the primary functions and criteria of neutralizing the hazards, maximizing byproduct removal and minimizing waste generation. An initial list of some 20 probable alternatives was evaluated and refined down to six potentially viable alternatives at the end of the workshop. The six alternatives developed in the workshop were put into a scoring matrix that weighed each alternative against five important criteria that were identified during the workshop as keys to the success of the favored sodium cleanup alternative.

The results of the scoring matrix exercise identified the Optimized Baseline Approach (OBA) as the favored alternative by the wash water project team. This reaffirmed the recommendations of the sodium cleanup specialists in a panel discussion held at the conclusion of the workshop. The OBA consists of leaving all major components of the primary system in place, and breaching certain components with a penetrating device to allow circulation of steam and wash water through the components. The primary system vessel would be filled with wash water and used to react and dissolve the majority of residual sodium left in the primary system. This alternative removes most of the remaining sodium and minimizes the waste volume. 
The path forward includes developing the OBA into a well engineered solution for achieving RCRA clean closure of the EBR-II Primary Reactor Tank system. Several high level tasks are also part of the path forward such as reassigning responsibility of the cleanup project to a dedicated project team that is funded by the DOE Office of Environmental Management, and making it a priority so that adequate funding is available to complete the project. Based on the experience of the sodium cleanup specialists, negotiations with the DEQ will be necessary to determine a risk-based de minimus quantity for acceptable amount of sodium that can be left in the reactor systems after cleanup has been completed. 



\section{ACKNOWLEDGMENTS}

The authors would like to thank the workshop participants, particularly Dr. Collin Knight, Dr. Steven Sherman and Dr. J. A. "Bert" Michelbacher for providing extensive historical and technical background information. We also would like to acknowledge the Department of Energy Office of Environmental Management for funding this work. 



\section{CONTENTS}

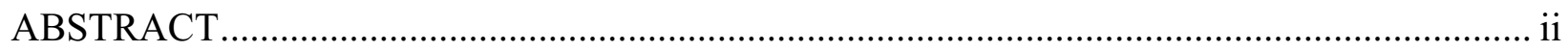

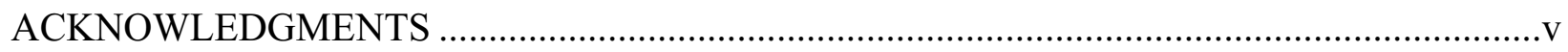

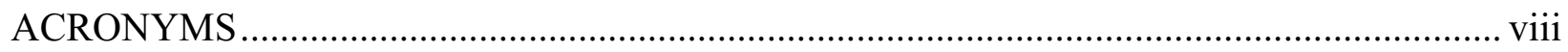

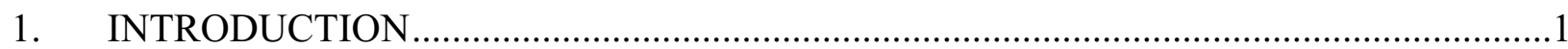

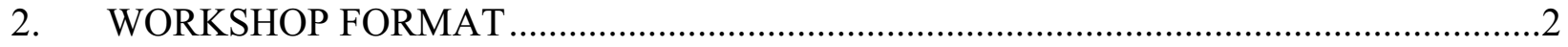

3. ALTERNATIVES EVALUATION AND RECOMMENDATION ..................................

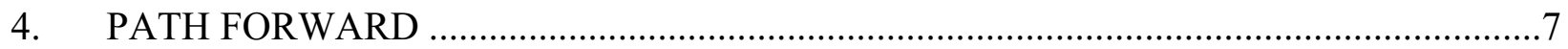

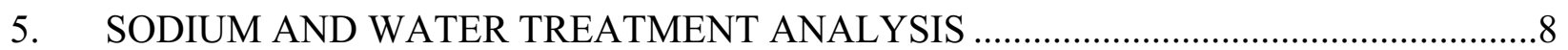

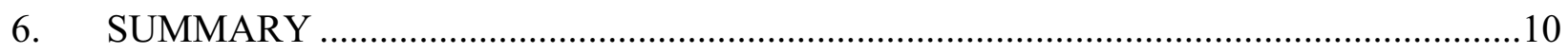

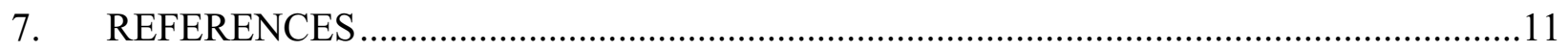

FIGURES

Figure 1. Name.EBR-II Reactor, Sodium Processing Facilities and Heat Exchangers ..................1

Figure 2, Primary Tank System of EBR-II. ......................................................................

Figure 3, Reactor System Inside Primary Tank with IHX Behind on Right. .............................7

TABLES

Table 1, Alternatives Evaluation Raw Scoring and Criteria Weighting Values...........................5

Table 2, Overall Weighted Alternative Scores and Acceptance Level.....................................6

Table 3, Estimated Location and Quantity of Residual Sodium in the Primary Tank...................8

Table 4, Estimated Radioactivity of Residual Sodium and Wash-Water Concentration ...............9 


\section{ACRONYMS}

ALARA As-Low-As-Reasonably-Achievable (minimizing radiation dose)

CERCLA Comprehensive Environmental Response, Compensation, and Liability Act

D\&D Decontamination and Decommissioning

DEQ Idaho Department of Environmental Quality

DOE-EM U.S. Department of Energy Office of Environmental Management

DOE-NE U.S. Department of Energy Office of Nuclear Energy, Science and Technology

EBR-II Experimental Breeder Reactor-II

ICDF Idaho CERCLA Disposal Facility

IHX Intermediate Heat Exchanger

INL Idaho National Laboratory

INTEC Idaho Nuclear Technology and Engineering Center

IWTU Integrated Waste Treatment Unit

MFC Materials and Fuels Complex (formerly ANL-W)

NaK Sodium Potassium Alloy (used as a reactor coolant)

OBA Optimized Baseline Approach

RCRA Resource Conservation and Recovery Act

RWMC Radioactive Waste Management Complex

RTC Reactor Technology Complex (formerly Test Reactor Area)

SME Subject Matter Expert

SPF Sodium Processing Facility

VE Value Engineering 


\section{INTRODUCTION}

The Experimental Breeder Reactor-II (EBR-II) Wash-Water Workshop was convened to determine the best method by which the EBR-II primary tank system could be flushed clean to meet environmental closure requirements. The system currently contains a small amount of reactive sodium and does not meet the requirements for "clean closure" under the Resource Conservation and Recovery Act (RCRA). Experts from two countries (U.S. and Great Britain) were brought together in a facilitated workshop to determine if filling the EBR-II primary vessel with water, and draining it (perhaps several times) would be the most effective method of accomplishing the objective. Results from the workshop include a number of recommendations and a path forward to accomplish this work. The notes from the workshop are presented in detail in Appendix A. ${ }^{1}$ This report briefly captures the main points of the workshop and further evaluates the six alternatives developed during the workshop, and provides a path forward for the best alternative based on the assumptions and information developed for the workshop. The recommended workshop alternative (by consensus and evaluation) is the Optimized Baseline Approach (OBA).

The EBR-II facility at the Materials and Fuels Complex (MFC) of the Idaho National Laboratory (INL) was designed and built to test the fuel cycle operations for the second generation of fast neutron breeder reactors. The EBR-II achieved criticality in 1965 and operated continuously for 30 years. A breeder reactor produces more nuclear fuel than it consumes by converting "fertile" uranium (U-238) into fissile plutonium (Pu-239). The $\mathrm{Pu}-239$ may then be used to fuel the nuclear reaction. A "fast neutron" type of breeder reactor does not use a moderator, such as water, to slow the fission causing neutrons, but instead allows a "fast" neutron that is more efficient for converting U-238 to Pu-239. Most fast breeder reactors use a liquid metal, predominantly metallic sodium or a sodium/potassium eutectic alloy (commonly referred to as $\mathrm{NaK}$ ), to cool the reactor.

\section{Figure 1, EBR-II Reactor, Sodium Processing Facilities and Heat Exchangers}

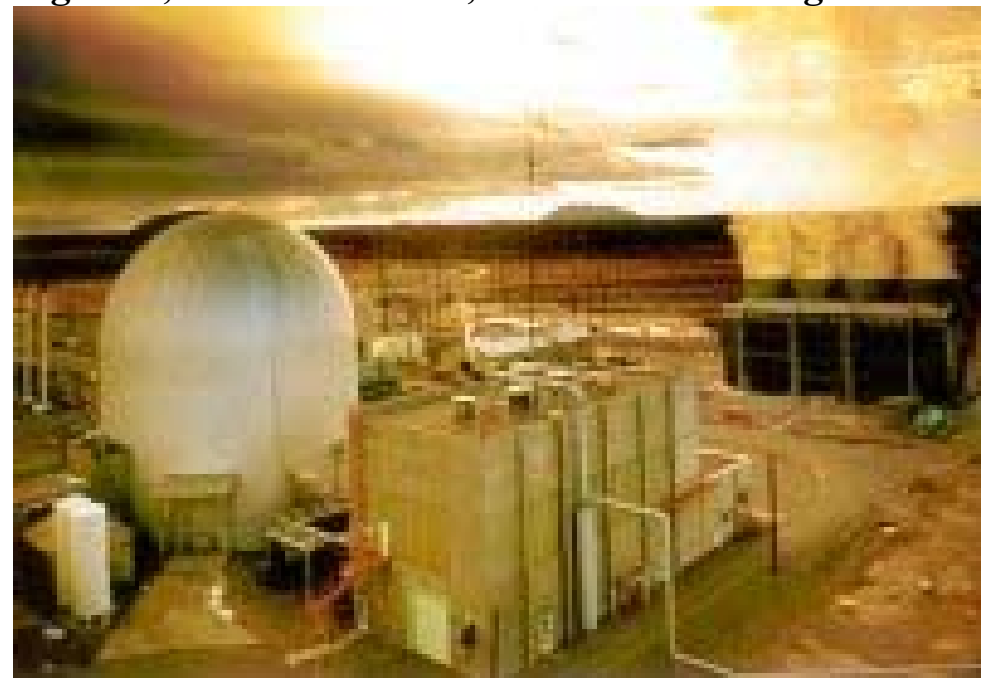


Liquid metal cooled reactors containing sodium or NaK present a difficult cleanup task. Sodium metal and $\mathrm{NaK}$ are very reactive and must be isolated from water and air. They may spontaneously burst into flame if in contact with any moisture. For this reason great care is taken when using sodium metal to ensure it remains within a dry, inert atmosphere (typically argon or nitrogen), especially when used as a coolant in nuclear reactors. The treatment of spent sodium is also hazardous, resulting in critical injuries. ${ }^{2}$ As recently as 2007 an industrial plant in Florida using sodium metal as part of its process exploded killing four workers. ${ }^{3}$

Only a small amount of reactive sodium remains in the EBR-II reactor system. About 130,000 gallons of the sodium was drained from the primary and secondary coolant systems in the early 2000s. This material was reacted at the Sodium Processing Facility (SPF) at the INL to make sodium hydroxide which was disposed of at the Radioactive Waste Management Complex (RWMC) at the INL. Moist carbon dioxide was then introduced into the primary tank and secondary system to convert the remaining sodium into sodium bicarbonate. By analyzing the generation of hydrogen and other factors it is estimated that currently only about 100 gallons of sodium remain in the primary tank. This material is mainly located in hard to reach areas that do not have an adequate drain path or free gas exchange with the primary tank atmosphere. This actually amounts to a very small quantity of sodium (about $1 / 1000$ of the primary system volume) that probably constitutes very little hazard, but the facility RCRA permit requires that all of the reactive sodium metal and reaction byproducts be removed before closure (within the next 12 years). ${ }^{4}$

The next phase of the closure process would be to remove the large reactor components and wash everything to neutralize the remaining sodium. This will likely be a difficult process because of the soldering affect of sodium metal and the buildup of sodium bicarbonate in the tank would probably prevent some of the components from being withdrawn from the vessel. Also, washing all tank surfaces and components will likely generate massive amounts (a minimum of 100,000 gallons) of contaminated water that must be treated and managed. The OBA, that will be discussed later, develops processes to breach the large components and leave them in place during treatment. As part of the optimized approach a de minimus value of sodium that may be left in the vessel will be determined, analyzed for risk (hazard), and negotiated with the Idaho Department of Environmental Quality (DEQ) prior to beginning the wash.

\section{WORKSHOP FORMAT}

A facilitated meeting was held on February 19-20, 2008 in the Bennion Student Union Building at University Place in Idaho Falls, Idaho. The primary objective was to evaluate methods to remove the residual sodium from the Experimental Breeder Reactor (EBR-II) primary system. Because the baseline approach produces a large amount of caustic waste water and other waste streams, such as metal, this meeting was organized to gather lessons learned from other sodium cleanup sites and develop alternatives to minimize the waste streams from the EBR-II cleanup. Also noted during the workshop, the resulting radiation dose from the baseline approach would be significant. Along with the INL 
Subject Matter Experts (SME) and the INL Wash Water Team, national and international specialists were brought in to participate in the meeting. ${ }^{1}$

A structured, facilitated process was followed using Value Engineering (VE) techniques to gather information, identify functions, develop alternatives, and select the top alternatives for further analysis. VE uses facilitation, function analysis, and a formal job plan to improve product or process quality, reduce cost, maintain quality, and build teamwork. The formal job plan is Preparation/Planning, Information Gathering, Creativity, Evaluation, and Development/Path Forward.

After the presentation of EBR-II background and current status, the team developed the functions and criteria that the alternatives would need to meet and what the evaluation of the criteria would use. The three primary functions were identified as neutralize hazards, maximize byproduct removal, and minimize waste. Alternatives for sodium cleanup were brainstormed based on cleaning the primary tank system only; treating the components in place if possible; and meeting RCRA clean closure requirements. Each identified alternative was discussed to determine how it might be used, and how well it addressed the three main functions. The team combined and refined the list to produce full alternatives that would meet the RCRA clean closure criteria. Finally, the team discussed the advantages and disadvantages of each alternative relative to the process and the results. See Appendix A for the initial evaluation table used to narrow-down the list to six viable alternatives.

One of the final activities of the meeting was a discussion with the sodium metal specialists about their perspectives on EBR-II primary system cleanup. While there were differences in cleanup recommendations, all agreed that developing a good and consistent relationship with the regulators would be critical to the success of the project. They also stressed that knowing the desired end state for the EBR-II reactor would be helpful in determining the best alternative for residual sodium cleanup. The team accomplished the objectives of this phase of the project through their subject matter knowledge and dedication to resolving the issues associated with sodium waste. The specialists were open and forthcoming with ideas and provided excellent advice on choosing a path forward.

\section{ALTERNATIVES EVALUATION AND RECOMMENDATION}

Building on the results of the workshop, the team was able to develop metrics to support the evaluation of the wash-water alternatives and assign numerical support for one alternative. In addition to the evaluation criteria and alternatives that were developed, a great deal of discussion was provided that leads to the development of a "path-forward." The path-forward will be discussed in greater detail in a separate section of this report, but it involves several "high-level" decisions that should be implemented in order for the recommended alternative to be developed and implemented. The baseline or any alternatives would require some additional engineering development prior to implementation. In essence, no progress on the primary tank wash down or RCRA cleanup should be pursued before addressing the items listed in the "path-forward" discussion. 
Figure 2, Primary Tank System of EBR-II.

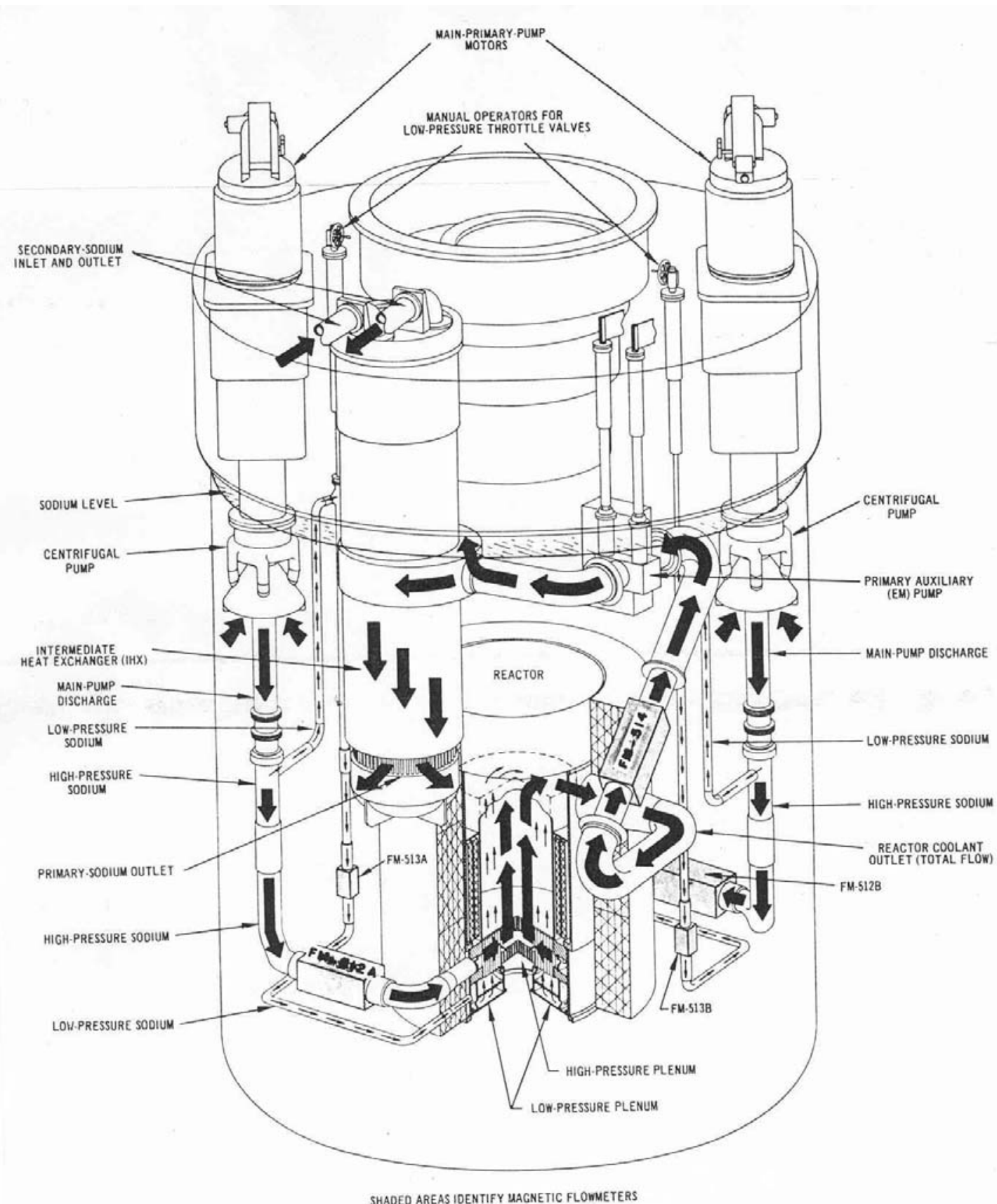

The wash-water evaluation team began the task of developing the discussions and data coming from the workshop into a recommendation. A matrix of the six alternatives finalized in the workshop (through brainstorming and expert analysis) was developed that would allow scoring of the alternatives versus several common cleanup project criteria. 
This matrix is shown in Table 1. The team also developed a weighting for the criteria and a method of assigning a numerical score to the individual criteria. The numerical exercise represents a strong recommendation that the Optimized Baseline Approach be adopted. This affirms the consensus of the workshop that also found this to be the recommended alternative among the panel of sodium cleanup specialists.

Table 1. Alternatives Evaluation Raw Scoring and Criteria Weighting Values

\begin{tabular}{|l|r|r|r|r|r|}
\hline Alternative & \multicolumn{1}{|l|}{ Cost } & Schedule & Dose & Effectiveness & $\begin{array}{l}\text { Future } \\
\text { Impact }\end{array}$ \\
\hline Weighting of Criteria & $\mathbf{2 6}$ & $\mathbf{1 1 . 5}$ & $\mathbf{3 1}$ & $\mathbf{1 9}$ & $\mathbf{1 2 . 5}$ \\
\hline Optimized (OBA) & 24 & 24 & 24 & 25 & 24 \\
\hline High Temp Steam & 23 & 22 & 22 & 21 & 21 \\
\hline Grout & 19 & 21 & 21 & 16 & 16 \\
\hline Partial Fill and Steam & 17 & 16 & 16 & 15 & 15 \\
\hline No Action & 18 & 18 & 18 & 10 & 10 \\
\hline Baseline & 15 & 15 & 11 & 17 & 17 \\
\hline
\end{tabular}

Table 1 shows the weighting of the criteria that was used in the mathematical analysis of the options. Each of the criteria was assigned a weighted value depending on its importance to the overall project based on the discussion of those criteria during the workshop. One of the lesser developed criteria going into the workshop, that of dose (ALARA concerns), turned out to be an important factor for the evaluation. The baseline alternative fared poorly in this criteria as the baseline did not take into account the large amount of dose and the difficulties in treating large, highly radioactive components. ${ }^{4}$ Another great concern was the relative perceived cost of each option. Cost was typically judged as lower (given a higher score) if fewer components were removed and if less waste would be generated as a result of the alternative. Again, all the alternatives were judged higher than the baseline with respect to cost. The effectiveness of performing the task considers how well a perceived option would neutralize the hazard and remove the byproducts. Finally, future impact and schedule were weighted approximately the same, with future impact (how versatile an alternative would be if plans changed later or additional remediation were necessary) being a little higher than accomplishing the tasks in less time.

After collecting the raw scores of the six alternatives and weighting them based on the criteria, adjusted scores were given to the individual alternatives. The weighted scores are given in Table 2 along with the possible score and percentage of that score that was given to that alternative. Again, with weightings applied as discussed above, the OBA was strongly favored (over $80 \%$ acceptance) with a more traditional steam/sodium reaction placing a strong second. These two options are seen as having high efficiency, allowing large components to be left in place during treatment (with some equipment modifications) and minimizing secondary wastes. Interestingly, a sensitivity evaluation shows that neither small changes in scoring (deviations in individual scores) nor in weighting (with or without weighting) really detract from the position of these two 
alternatives. Also note that these two methods are not unusual and are among the industry-accepted methods of sodium cleanup.

Table 2, Overall Weighted Alternative Scores and Acceptance Level

\begin{tabular}{|c|c|c|c|}
\hline Alternative & Score & Possible & \% \\
\hline Optimized (OBA) & 24.2 & 30.0 & 80.6 \\
\hline High Temp Steam & 21.9 & 30.0 & 73.2 \\
\hline Grout & 18.9 & 30.0 & 63.0 \\
\hline $\begin{array}{c}\text { Partial Fill and } \\
\text { Steam }\end{array}$ & 15.9 & 30.0 & 53.2 \\
\hline No Action & 15.5 & 30.0 & 51.6 \\
\hline Baseline & 14.4 & 30.0 & 48.0 \\
\hline
\end{tabular}

Most of the alternatives, especially the OBA, provide better scores than the Baseline. This is because these alternatives favor leaving the large components in place. The baseline approach includes removing certain large components, including the intermediate heat exchanger (IHX), bayonet heaters, shutdown coolers and nozzles prior to filling the system with wash-water to react with the remaining sodium, and dissolving the reaction products (sodium bicarbonate, sodium carbonate and sodium hydroxide). The OBA differs from the baseline by leaving the large components in place and puncturing them with a penetrating device, thus allowing the water or steam to flow through those components and react with the residual sodium. This substantially reduces waste volumes, greatly reduces radiation doses and decreases the overall schedule by eliminating the need to remove the large components. The high temperature steam option reduces waste beyond either of the baseline options. The steam alternative may improve the reduction of the reactive sodium hazard, because it flows into difficult geometries better than water, but may not wash out reaction product quite as well. Steam has gained acceptance for in-situ sodium treatment in the sodium cooled reactor community in Great Britain.

Grouting the primary tank in place was a novel alternative that had not been discussed before it was suggested at the workshop. This option also involves leaving all the primary system components in place and simply filling the tank up with grout. Though grouting typically means using a Portland cement based material, other materials, including a paraffin-based grout, were discussed. Grouting is a very attractive option because no secondary waste is generated for further treatment or disposal. However, it does not satisfy all the required criteria, because it may not fully react with nor will it remove any sodium products from the primary system. This may not be an overwhelming disadvantage though, because the hazardous sodium would be encapsulated and isolated. In addition none of the other alternatives would likely remove $100 \%$ of the sodium either.

The partial steaming approach combines part of the optimized approach with heating up the primary tank to react the remaining sodium in the upper portions of the tank with steam. This option likely has little advantage over either the optimized or the full steam option. The No Action alternative is particularly attractive because of its savings in time, 
waste and money. It does nothing to reduce the hazard though and was not favored in anyone's opinion, though there is something to be said for leaving the residual sodium and allowing ambient atmosphere to enter the primary tank.

Figure 3, Reactor System Inside Primary Tank with IHX Behind on Right.

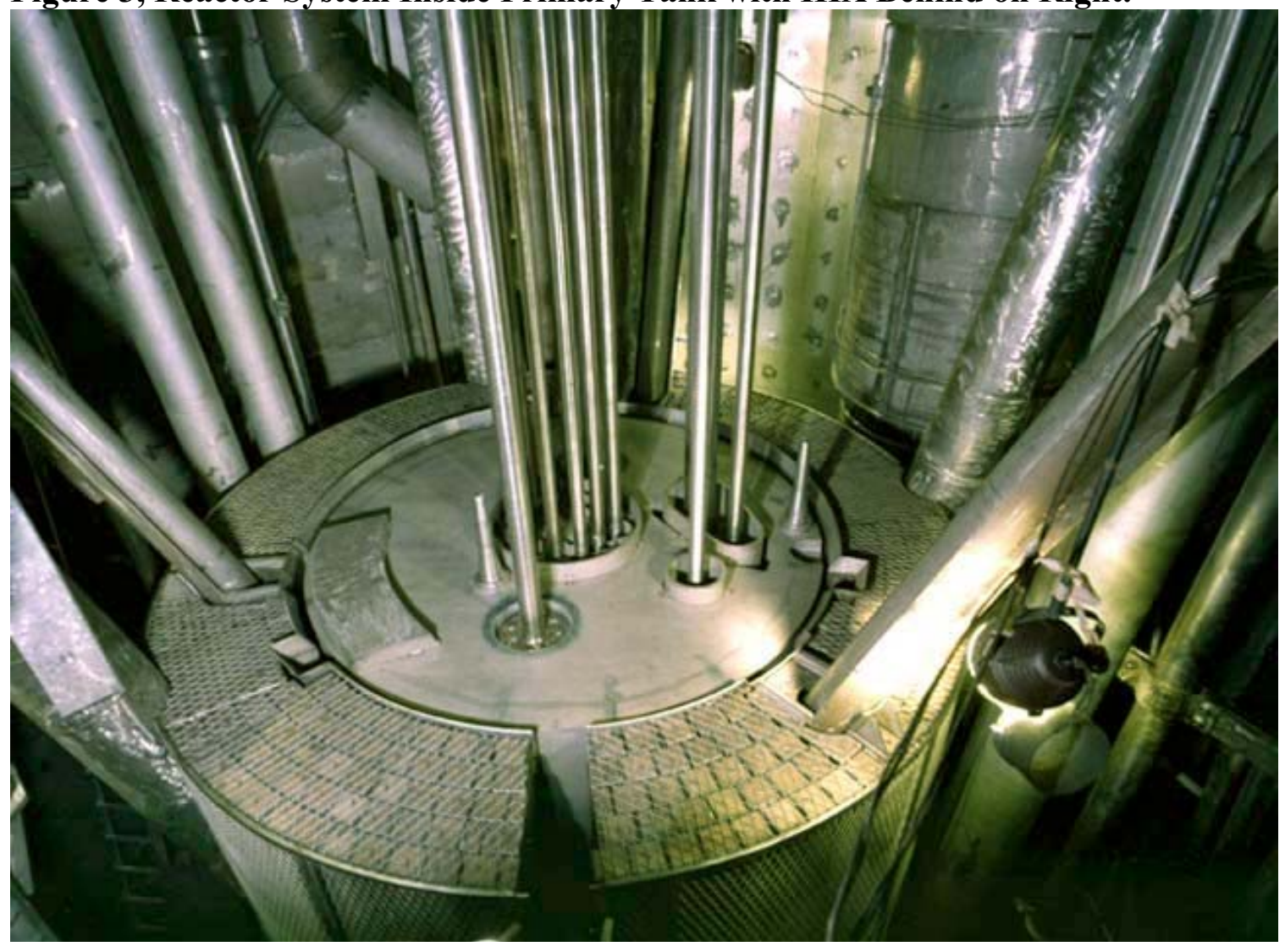

\section{PATH FORWARD}

Tackling several high-level activities is necessary for completing the closure of the EBRII Primary Reactor Tank System. While the recommended alternative is to develop a well engineered Optimized Baseline Alternative, real progress will require initiation of most of these high level tasks. A number of these tasks were discussed during the workshop and are listed below. Other activities outside of the workshop scope, that pertain mainly to general closure and demonstrating annual progress to the regulators, are developed in the 2006 RCRA closure report listed in the references at the end of this report. $^{2}$ The most important tasks that were brought out in the workshop are:

- Transfer the project out of DOE-NE to DOE-EM.

- Prioritize the closure project (within DOE-EM) so that it can be funded.

- Develop a "project" mentality with a dedicated project team.

- Negotiate a de minimus value with the Idaho Department of Environmental Quality (DEQ) for how much sodium can be left behind based on level of risk. 
Not all of these tasks need to be completed immediately in order to move forward with the OBA. However, little progress is going to be shown without spending substantially more resources. Without transferring the project, DOE-NE could fund engineering studies and hazard analyses that feed into discussions with DEQ to determine a quantity of sodium that could remain (the current permit states that the large components must be removed and all sodium reacted and removed). The sodium treatment experts all suggested that an acceptable quantity of residual sodium should be negotiated and agreed upon with DEQ, because it is nearly impossible to remove all of the residual sodium from the tank. Little real risk is associated with small amounts of sodium left in the primary tank system. A consensus was also held that resources should be retained and not lost to attrition by developing this work into a large project and integrating it with D\&D or future activities.

\section{SODIUM AND WATER TREATMENT ANALYSIS}

To address the impact of the sodium and contaminated water discussed in this wash-water project it was necessary to develop some additional information concerning the quantity and location of the remaining sodium and the characteristics of the produced wash-water. The data shown in Table 3 below, is taken from two INL reports ${ }^{4,5}$ written in 2006. As noted, about $650 \mathrm{~kg}$ (668 liters, about 176 gallons) of unreacted sodium metal and $\mathrm{NaK}$ remain in the primary tank system.

Table 3, Estimated Location and Quantity of Residual Sodium in the Primary Tank.

\begin{tabular}{|l|c|c|}
\hline Location & $\begin{array}{l}\text { Amount Before } \\
\text { Carbonation (L) }\end{array}$ & $\begin{array}{l}\text { Amount After } \\
\text { Carbonation (L) }\end{array}$ \\
\hline High Pressure Plenum (HPP) & 125 & 66 \\
\hline HPP Inlet Pipes & 117 & 49 \\
\hline $\begin{array}{l}\text { Reactor Baffles and } \\
\text { Equipment }\end{array}$ & 104 & 99 \\
\hline Fuel Handling Equipment & 12 & 4 \\
\hline Press. Transmitter Piping & $8(\mathrm{NaK})$ & $8(\mathrm{NaK})$ \\
\hline Primary Tank Bottom & 473 & 0 \\
\hline Intermediate Heat Exchanger & 151 & 140 \\
\hline $\begin{array}{l}\text { Primary Tank Heater } \\
\text { Thimbles }\end{array}$ & 112 & $190(\mathrm{NaK})$ \\
\hline Shutdown Cooler Bayonets & $190(\mathrm{NaK})$ & \\
\hline
\end{tabular}

After the bulk of the sodium was drained from the EBR-II primary sodium system, residual amounts of sodium remained at various places in the primary system. Precise locations and estimates of residual quantities at each location were determined by studying the engineering drawings. Twenty-four unique locations with hydraulic low points capable of retaining liquid sodium were identified within the EBR-II primary sodium system ${ }^{5}$. The potential quantity of residual sodium for each location listed in the 
table (Residual Sodium Deposits in EBR-II Primary Tank) was calculated using the internal geometry from the drawings and the elevation of the drain path for each identified location. The primary assumption used in deriving the volume calculations was that, except for locations with no outlets, the liquid sodium drained towards the bottom of the primary vessel as the bulk sodium metal was withdrawn. Based upon visual observations via video camera, vertical surfaces were assumed to have negligible sodium residue on them. In addition to the 24 locations mentioned above, some sodium is also left in the IHX, Primary Tank Heater Thimbles, and NaK in the Shutdown Cooler Bayonets.

The column "Amount After Carbonation" lists the quantity of sodium metal remaining after the carbonation treatment process was stopped. In some locations geometric restrictions prevented carbonation of any of the residual sodium, in other locations a portion of the residual sodium metal was reacted, and in other locations it was expected that $100 \%$ of residual sodium reacted with the $\mathrm{CO}_{2}$ and water to form carbonates. In summation the EBR-II primary sodium system was estimated to contain about 1550 liters of residual sodium metal before the carbonation treatment. The carbonation process stabilized the majority of sodium by reaction to form sodium carbonates. Based on the study of the engineering drawings and process data from the carbonation process, over 650 liters of unreacted sodium metal remain in the primary system.

Table 4, Estimated Radioactivity Concentration of Wash-Water

\begin{tabular}{|c|c|c|c|c|c|c|}
\hline Radionuclide & $\begin{array}{l}1994 \\
\text { Analyses } \\
\text { (current } \\
\text { value) }\end{array}$ & Units & $\begin{array}{l}\text { Estimated } \\
\text { Total } \\
\text { (2008) }\end{array}$ & Units & $\begin{array}{l}\text { Concentration } \\
\text { in Wash- } \\
\text { Water }\end{array}$ & Units \\
\hline $\mathrm{H}-3$ & 1.10E-07 & $\mathrm{Ci} / \mathrm{g}$ & $2.49 \mathrm{E}-02$ & $\mathrm{Ci}$ & $7.33 \mathrm{E}-08$ & $\mathrm{Ci} / \mathrm{l}$ \\
\hline $\mathrm{Na}-22$ & $2.82 \mathrm{E}-09$ & $\mathrm{Ci} / \mathrm{g}$ & $6.39 \mathrm{E}-04$ & $\mathrm{Ci}$ & 1.88E-09 & $\mathrm{Ci} / \mathrm{l}$ \\
\hline Mn-54 & $8.28 \mathrm{E}-15$ & $\mathrm{Ci} / \mathrm{g}$ & 1.88E-09 & $\mathrm{Ci}$ & $5.52 \mathrm{E}-15$ & $\mathrm{Ci} / \mathrm{l}$ \\
\hline Sr-89 & $2.10 \mathrm{E}-39$ & $\mathrm{Ci} / \mathrm{g}$ & $4.76 \mathrm{E}-34$ & $\mathrm{Ci}$ & $1.40 \mathrm{E}-39$ & $\mathrm{Ci} / \mathrm{l}$ \\
\hline Sr-90 & $9.42 \mathrm{E}-11$ & $\mathrm{Ci} / \mathrm{g}$ & 2.14E-05 & $\mathrm{Ci}$ & $6.29 \mathrm{E}-11$ & $\mathrm{Ci} / \mathrm{l}$ \\
\hline $\mathrm{Ag}-110 \mathrm{~m}$ & $3.55 \mathrm{E}-15$ & $\mathrm{Ci} / \mathrm{g}$ & $8.06 \mathrm{E}-10$ & $\mathrm{Ci}$ & $2.37 \mathrm{E}-15$ & $\mathrm{Ci} / \mathrm{l}$ \\
\hline Sn-113 & $2.17 \mathrm{E}-20$ & $\mathrm{Ci} / \mathrm{g}$ & $4.93 \mathrm{E}-15$ & $\mathrm{Ci}$ & $1.45 \mathrm{E}-20$ & $\mathrm{Ci} / \mathrm{l}$ \\
\hline Sb-125 & $2.66 \mathrm{E}-10$ & $\mathrm{Ci} / \mathrm{g}$ & 6.04E-05 & $\mathrm{Ci}$ & $1.78 \mathrm{E}-10$ & $\mathrm{Ci} / \mathrm{l}$ \\
\hline Cs-134 & $2.65 \mathrm{E}-11$ & $\mathrm{Ci} / \mathrm{g}$ & $6.01 \mathrm{E}-06$ & $\mathrm{Ci}$ & $1.77 \mathrm{E}-11$ & $\mathrm{Ci} / \mathrm{l}$ \\
\hline Cs-137 & 1.71E-08 & $\mathrm{Ci} / \mathrm{g}$ & $3.88 \mathrm{E}-03$ & $\mathrm{Ci}$ & $1.14 \mathrm{E}-08$ & $\mathrm{Ci} / \mathrm{l}$ \\
\hline Po-210 & $2.35 \mathrm{E}-21$ & $\mathrm{Ci} / \mathrm{g}$ & $5.33 \mathrm{E}-16$ & $\mathrm{Ci}$ & $1.57 \mathrm{E}-21$ & $\mathrm{Ci} / \mathrm{l}$ \\
\hline Pu-239 & $3.15 \mathrm{E}-13$ & $\mathrm{Ci} / \mathrm{g}$ & $7.15 \mathrm{E}-08$ & $\mathrm{Ci}$ & $2.10 \mathrm{E}-13$ & $\mathrm{Ci} / \mathrm{l}$ \\
\hline
\end{tabular}

An analysis of the radioactivity of the residual sodium confirms that, while the radiation levels have decayed to fairly low levels since the shutdown of the EBR-II reactor, the residual radioactivity must be managed. Table 4 shows the sodium analysis performed in $1994^{6}$ which examined some 25 different radionuclides that were expected to be present in the sodium coolant. Some of these, such as Co-58 and Co-60 proved to be below detection levels in the original analyses. Others, such as $\mathrm{Sn}-117 \mathrm{~m}$ and I-131 decayed to such low levels (less than 1E-100) over the last 13 years that they had no practical 
contribution to the radiation levels. In fact, the only real problem radionuclides (those exceeding picocurie levels in the wash-water) are $\mathrm{H}-3, \mathrm{Na}-22, \mathrm{Sr}-90, \mathrm{Sb}-125, \mathrm{Cs}-134$ and Cs-137.

Even those levels of cesium and other radionuclides are not high enough to cause significant problems for disposal. All evaporation pond liquid disposal facilities at the INL will accept radioactive water at those levels. The Reactor Technology Complex (RTC) evaporation pond allows water at levels up to $20 \mathrm{mCi} / \mathrm{L}^{7}-$ approximately 5 orders of magnitude higher than the level anticipated for this wash water. In addition to the RTC evaporation pond, this water could be sent to the Idaho CERCLA Disposal Facility (ICDF) or the new Idaho Waste Treatment Unit (IWTU) at the Idaho Nuclear Technology Engineering Center (INTEC). Another option is off-site disposal at Energy Solutions in Utah.

The team briefly evaluated these different disposal options and found that some were quite attractive. Off-site disposal is estimated to cost $\$ 17 /$ gallon while on-site disposal ranged from an estimated $\$ 5 /$ gallon for the evaporation ponds to perhaps as much as $\$ 100 /$ gallon for the IWTU (no real costs have been quoted for the IWTU for non-INTEC Tank Farm Waste at this time). For the estimated 90,000 gallons of wash-water waste from the primary tank the total on-site disposal costs would probably be in the $\$ 400,000$ range. Since this waste can be managed more effectively with the OBA, some savings (perhaps $\$ 100,000$ ) could be realized. However, since the overall cost for RCRA clean closure of the EBR-II facility is expected to run over $\$ 20,000,000$, the cost of the primary tank wash-water disposal is not a significant budget concern to the project as a whole, and will probably not drive the project to extreme efforts in cost avoidance.

\section{SUMMARY}

The Optimized Baseline Approach was the alternative method recommended by the panel of sodium cleanup specialists at the workshop, and confirmed as the best alternative by the weighted scoring matrix analysis performed by the wash water project team. This alternative was chosen because it scored the highest among the common project criteria in the matrix, and most importantly it reduced the quantity of waste that would be generated for disposal. As discussed in Path Forward section of the report, actual progress towards clean closure of EBR-II will require elevating this activity to a priority project within DOE-EM. This will require transferring ownership of the EBR-II facilities from DOE-NE to DOE-EM. In addition, an acceptable de minimus level of sodium left in the primary system must be negotiated with DEQ, as it is practically impossible to remove every last gram of sodium from the system. 


\section{REFERENCES}

1. Braase, L., "EBR-II Wash Water Evaluation Expert Panel Review”, Letter LAB-01-08, March 7, 2008.

2. Routley, G. J., "Sodium Explosion Critically Burns Firefighters in Newton, Massachusetts, October 1993.

3. Johnson, J., "Florida Explosion Investigation Yields Preliminary Results," Chemical and Engineering News, January 14, 2008.

4. Sherman, S.R., et al, "Experimental Breeder Reactor II RCRA Treatment Cost Estimate," INL/EXT-06-01158 R1, February 2006.

5. Sherman, S. R., Knight, C. J., "Technical Information on the Carbonation of the EBR-II Reactor,” INL/EXT-06-01189, March 2006.

6. Analytical Laboratory Analysis Reports, Argonne National Laboratory - West, Report \#s 70(327), 328, 336, 363, 731, 783, 784, 797, 836, 837, 838, 871, 872, 927, 982, 983, 984, March - October 1994.

7. Welty, B. D., "Disposal of TRA-730 Catch Tank Rinsate Solution in the TRA-715 Evaporation Pond," INL EDF-5006, August 2004. 
Appendix A, EBR-II Wash Water Evaluation Expert Panel Review 


$\begin{array}{lllr}\text { Date: } & \text { March 19, } 2008 & & \\ \text { To: } & \text { Rick Demmer } & \text { MS 7113 } & 3-4277 \\ & \text { Richard Meservey } & \text { MS 3710 } & 6-1834 \\ \text { From: } & \text { Lori Braase } & \text { hori Draase } & \text { MS 3634 }\end{array}$

Subject: $\quad$ EBR-II Wash Water Evaluation

A facilitated meeting was held in Idaho Falls, Idaho at the Bennion Student Union Building on February 19-20, 2008. The primary objective was to evaluate methods to remove the residual sodium from the Experimental Breeder Reactor (EBR-II) primary system.

EBR-II, located at the Materials and Fuels Complex (MFC) at the Idaho National Laboratory (INL) was a sodium-cooled fast breeder reactor that operated for 30 years until 1994 when the United States Congress ordered it shutdown. By December 1996, 637 fuel assemblies were removed from the reactor core. The bulk of sodium was removed from the secondary and primary systems by 2001 . The facility was placed into a dormant and safe condition in 2002.

In December 2002, EBR-II became regulated under the Resource Conservation and Recovery Act (RCRA) waste permit. As a result, cleanup activities occurred from May 2004 through December 2005 to treat the 90,000 gallon primary tank with humidified $\mathrm{CO} 2$.

No additional clean up activities have occurred. Currently, there is activated stainless steel and approximately 100 gallons of sodium remaining in 24 pockets in the primary system. There was no funding allocated to this effort in FY-07; the facility is currently staffed with a minimum crew.

The RCRA permit requires yearly progress to demonstrate compliance. In addition, the permit is scheduled for renewal in 2012 and it may not be granted if yearly cleanup progress does not occur.

The RCRA permit defines the cleanup baseline for the primary tank system. In general terms, the primary system will be completely filled with water (or a caustic solution) to dissolve the sludge and carbonate. The components (heaters, coolers, covers, nozzles, etc.) will be pulled to demonstrate complete sodium reaction. Then the tank will be drained in order to do a final rinse for data collection. The tank will be closed in place until a final disposition path is chosen. 
Rick Demmer

March 19, 2008

Page 2

Since the baseline approach produces a large amount of waste water and other waste streams, such as metal, this meeting was organized to gather lessons learned from other sodium cleanup sites and develop alternatives to minimize the waste streams from the EBR-II cleanup. Along with the INL subject matter experts (SMEs) and the INL Wash Water Team, national and international specialists were brought in to participate in the meeting.

A structured facilitated process using Value Engineering (VE) techniques was followed to gather information, identify functions, develop alternatives, and select the top alternatives for further analysis. VE uses facilitation, function analysis, and a formal job plan to improve product or process quality; reduce cost; maintain quality; and build teamwork. The formal job plan is Preparation/Planning, Information Gathering, Creativity, Evaluation, and Development/Path Forward.

Background information on EBR-II history, cleanup, and status was provided by Steve Sherman of Savannah River National Laboratory (SRNL) who previously supported the EBR-II project. Additional information on sodium cleanup alternatives and lessons learned was provided by the sodium cleanup specialists, Peter Thompson, Ethan Consultancy, Ltd., UK AEA Dounreay, Scotland; Danny Swindle, Fermi, Detroit Edison; Bill Church, FFTF, Hanford; and Leonard Mason, UK AEA Dounreay, Scotland.

The team discussed the requirements and developed the functions that the sodium cleanup operation would need to perform. The three primary functions were identified as neutralize hazards, maximize byproduct removal, and minimize waste.

Alternatives for sodium cleanup were brainstormed based on the cleaning the primary tank system only; treating the components in place if possible; and meeting RCRA clean closure requirements.

Each brainstormed alternative was discussed to determine how it might be used and how well it addressed the three main functions. Then the team combined and refined the list to produce full alternatives that would meet the RCRA Clean Closure criteria.

Finally, the team discussed the Pros and Cons relative to the process and the results. See Appendix A for the initial evaluation table used to narrow-down the list to six viable alternatives, which the INL Water Wash Project Team will investigate and evaluate further.

One of the final activities of the meeting was a discussion with the sodium specialists about their perspectives on EBR-II primary system cleanup. While there were differences in cleanup recommendations, all agreed that developing a good and consistent relationship with the regulators would be critical to the success of the project.

The team accomplished the objectives of this phase of the project through their subject matter knowledge and dedication to resolving the issues associated with sodium waste. The specialists were open and forthcoming with ideas and excellent advice on choosing a path forward. 
Rick Demmer

March 19, 2008

Page 3

The attachment provides the material generated during the meeting. Presentations given during the meeting are available upon request. I enjoyed working with the team and look forward to potential future opportunities to support your project. Please let me know if you have questions or need further assistance.

Attachment

cc:

$\underline{\text { DOE-HQ }}$

S. Lien

Creative Engineers

C. Bohannon

Dounreay (UK AEA)

L. Mason

P. Thompson, Ethan Consultancy, Ltd

Fermi, Detroit Edison

D. Swindle

Hanford

B. Church

$\underline{\text { ICP }}$

D. Crisp, MS 1623

D. Gianotto, MS 3940

D. Nickelson, MS 3920 $\underline{\text { INL }}$

T. Carlson, MS 3405

L. Flatten, MS 6178

R. Grant, MS 3405

J. Heintzelman, MS 4107

C. Knight, MS 6180

J. Roach, MS 3710

M. Rubick, MS 7137

P. Smith, MS 6164

L. Squires, MS 6150

J. Thalgott, MS 6134

T. Zahn, MS 6178

VE Project File 2008-003

(w/o Attachments)

R. Klingler, MS 3780

L. Braase File: LAB-01-08

SRNL

S. Sherman

Uniform File Code: 8406

Disposition Authority: RD1-A-3

Retention Schedule: Cutoff after program/project completion, cancellation, or termination. Destroy 10 years after termination of project/program.

NOTE: Original disposition authority, retention schedule, and Uniform Filing Code applied by the sender may not be appropriate for all recipients. Make adjustments as needed. 


\section{EBR-II WASH WATER EVALUATION}

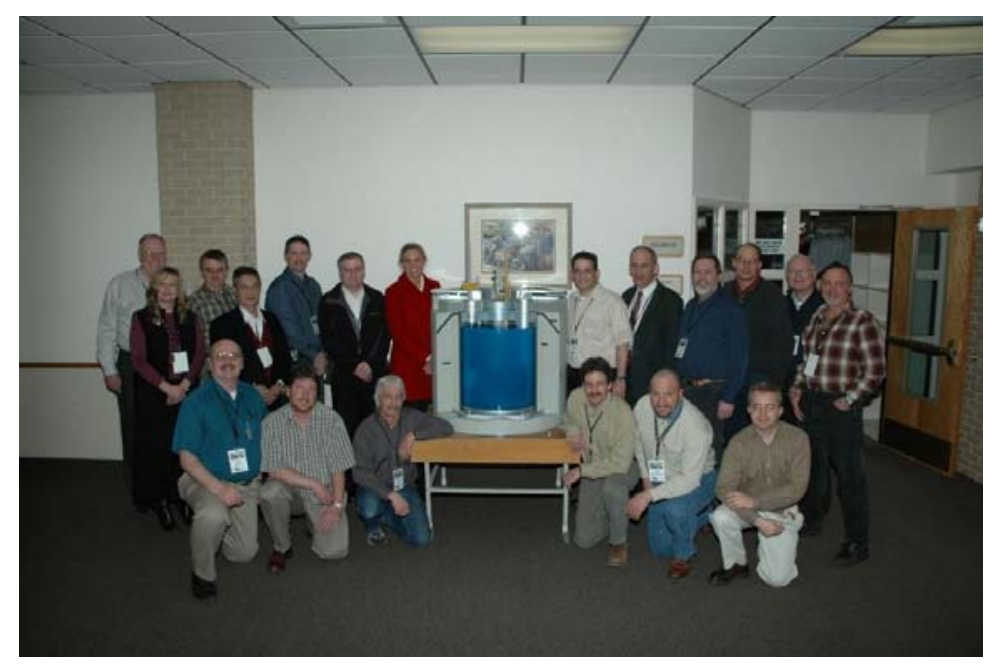

\section{Prepared for the INL Wash Water Project Team \\ By Lori Braase \\ Idaho National Laboratory \\ Systems Engineering Department}

March 7, 2008 


\section{TABLE OF CONTENTS}

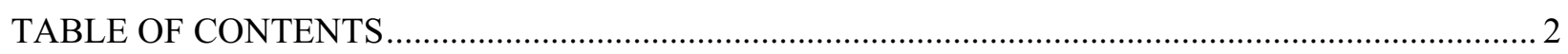

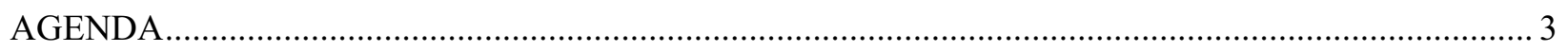

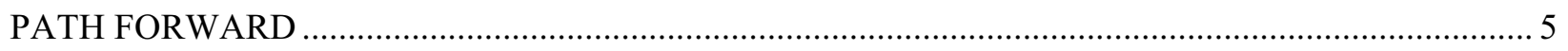

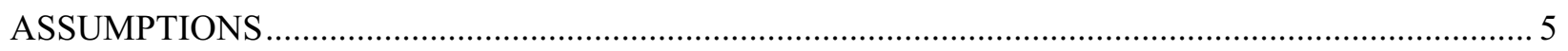

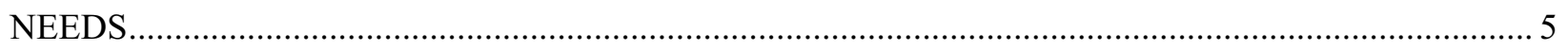

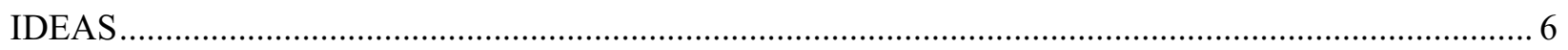

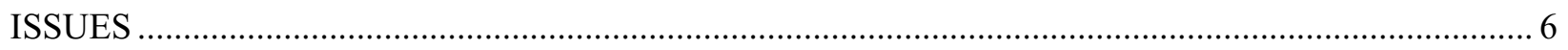

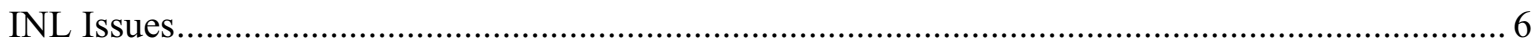

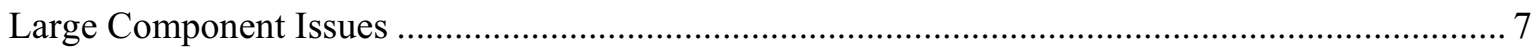

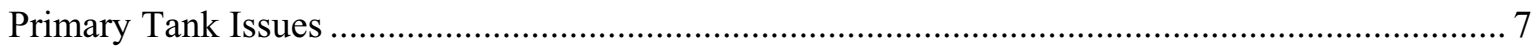

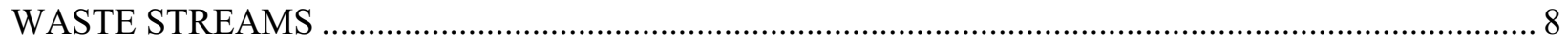

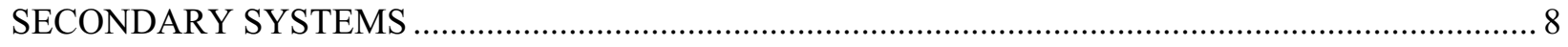

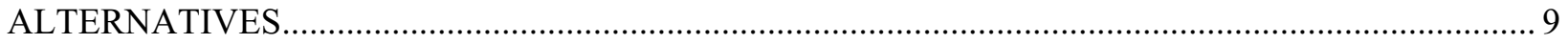

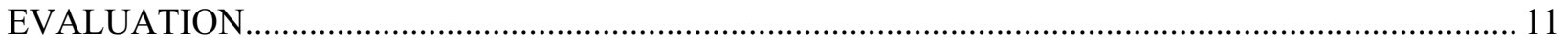

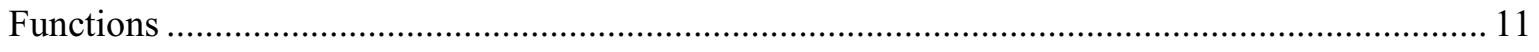

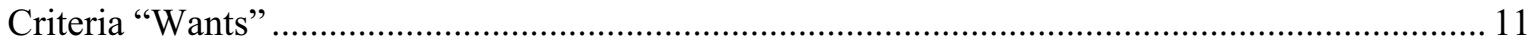

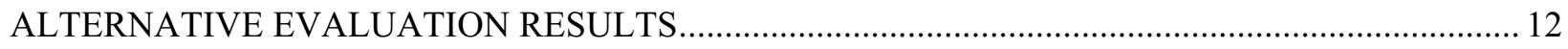

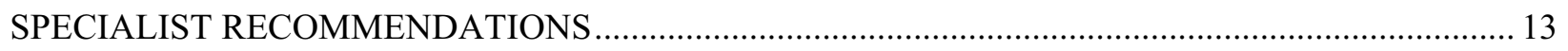

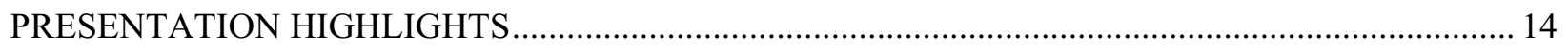

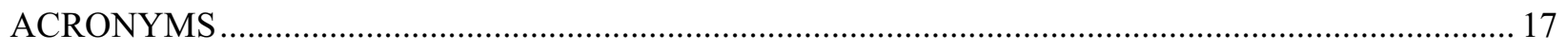

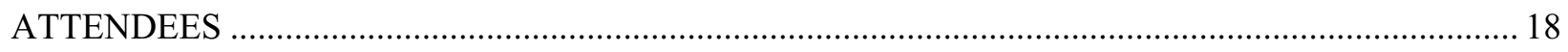

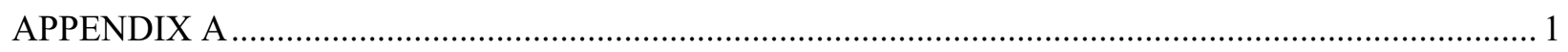




\section{EBR-II WASH WATER EVALUATION \\ February 19-20, 2008 \\ Bennion Student Union Building; Room 109}

\section{Objectives:}

- Evaluate methods to remove the sodium from the EBR-II primary system with minimal waste generation.

- Discuss the baseline water flush path in terms of safety and efficacy.

\section{AGENDA}

\section{Tuesday, February 19, 2007}

8:00 Working Breakfast

Welcome, Introductions, Agenda, \& Guidelines

8:30 Briefing on EBR-II Reactor History to Present Condition

8:50 EBR-II Cleanup Plans / Video

10:00 Break

Sodium Cleanup Alternatives

10:15 • UK AEA - Dounreay Overview

10:30 • USA-Fermi

10:45 • USA-FFTF

11:30 Develop Primary System Cleanup Functions

Noon Working Lunch: Identify Evaluation Criteria

Sodium Cleanup Alternatives (continued)

1:00 - Dounreay Process

1:30 • Epsom Salt and Water Jet

1:45 Brainstorm Alternatives to Clean the EBR-II Reactor's Primary System

2:30 Break

2:45 Refine / Combine / Discuss Alternatives

5:00 Adjourn
Rick Demmer /

Lori Braase

Steve Sherman

Steve Sherman /

Collin Knight

Peter Thompson

Danny Swindle

Bill Church
Leonard Mason

Leah Squires 
Wednesday, February 20, 2007

\begin{tabular}{|c|c|c|}
\hline $8: 00$ & Welcome / Review & \\
\hline $8: 15$ & EBR-II Primary Tank Chemicals & Rick Demmer \\
\hline 9:00 & Develop Viable Alternatives & \\
\hline $10: 00$ & Break & \\
\hline $10: 15$ & Evaluate Alternatives: Pro/Con Analysis & \\
\hline $11: 30$ & Lunch & \\
\hline $1: 00$ & Expert Panel Perspective & \\
\hline 2:00 & Develop Path Forward & \\
\hline $3: 00$ & Adjourn & \\
\hline
\end{tabular}




\section{PATH FORWARD}

- Issue meeting summary for team review. Incorporate comments and issue final document to all attendees. (Lori Braase)

- Develop Viable Alternatives (INL Wash Water Project Team)

- Identify comparative information

- Analyze alternatives

- Review the "needs"

- Develop actions

- Provide follow on information to the larger team.

- Note: Send questions to the specialists through one point of contact.

\section{ASSUMPTIONS}

- Regulators will be willing to negotiate on requirements for EBR-II RCRA Clean Closure.

- Adequate "venting" for excursions can be engineered.

\section{NEEDS}

- A unified integrated approach is needed for final D\&D disposition. A lifetime plan with a timeline (durations) should be developed that supports the project plan.

- Shielding requirements for ex-situ cleaning.

- Progress on other systems.

- Consistent and long term project team committed to this effort.

- Champion.

- What the regulators want.

- Consistent interfaces.

- Should appear as a project that is funded.

- Develop personal relationships with regulators. 


\section{IDEAS}

- Treat the hazard and then convince the regulators to leave some of the residual sodium in place.

- Make the "reasonable risk" case to the regulators. Show risks and alternatives.

- Generate a residual sodium limit with the regulators. Agree on how much sodium can be left in the systems.

- Look at ways to go from RCRA Clean to CERCLA Closure.

- Look for opportunities to close major footprint areas at the site. This frees up areas for reuse (short term).

- Develop a plan with the regulators on closure options after the completion of RCRA Clean Closure. It is important to get final approval to get out of RCRA (long term).

\section{ISSUES}

\subsection{INL Issues}

- Field work proposal.

- The INL is currently changing sections of the closure plan.

- There is no source of funding to establish a consistent project team that can maintain interface with the regulators.

- There appears to be a lack of direction, little leadership and no funding to go forward with the project. There is no cleanup project and no project team.

- There is no "relationship" with the regulator upon which to base acceptance of alternatives. This also relates to an unrealistic expectation of "no hazard left" after RCRA closure."

- There needs to be integration of long term D\&D plans with shorter term RCRA requirements.

- The baseline expectation of removing the large primary components is unrealistic.

- DOE has thus far seen little reason to prioritize this RCRA cleanup. 
- Minimal cleanup activity is required to work toward license renewal.

- Consider transfer of the project / facility to EM. This would require senior level management approval from EM and NE.

- Ensure the project remains on the NE funding list, even if funding is not available.

- BEA is considering the establishment of a new Waste Management group, which would include this project.

\subsection{Large Component Issues}

(Intermediate Heat Exchanger (IHX), heaters, shutdown coolers)

- The IHX may be 'frozen' in place and very difficult or impossible to remove.

- It may be possible to drill holes in the components to access the sodium.

- If the components are removed, they should be cleaned and cut up to access the sodium, then disposed of or placed back into the primary tank.

- It's preferable to treat components in place prior to filling the primary tank with water.

- Pulling the IHX from the tank may require excessive pressure from the crane.

- When pipes and components are cut in the tank, the sodium will be disturbed and could spread.

\subsection{Primary Tank Issues}

- It will be hard to know what is going on in the tank as it fills with water because there will be a bicarbonate layer on top of the sodium.

- Sodium hydride issues.

- There is bulk sodium present in systems where the majority of sodium was removed and the system cooled.

- Caustic has not been found in the primary tank (only sodium bicarbonate). However, it is something to consider. 


\section{WASTE STREAMS}

- Water Wash Waste Stream Disposal Options

- Lowest Cost RTC Evaporation Pond (715)

- Low to Medium Cost ICDF Evaporation Pond (INTEC)

- Medium to High Cost Evaporation and solidification in place with mobile equipment. (Grouting, concentration, simple absorption, etc.)

- Highest Cost IWTU - should be online by 2010

- Additional LLW Streams (some could be decontaminated and reused)

- Samples

- PPEs

- Tools and equipment

- Metal

\section{SECONDARY SYSTEMS}

- Take advantage of current expertise.

- Don't do anything to preclude primary tank closure.

- Nozzles are penetrations in the cover.

- Optimized baseline approach.

- Characterize storage holes and pits

- Cleanup holes and pits to reduce risk.

- Update existing plans with current cost and durations.

- Look at removing systems and facilities.

- Purification and chemistry loops.

- Look at proving technology to clean the secondary systems that is needed in the primary system.

- Take before and after pictures to show progress on systems. 


\section{ALTERNATIVES}

Alternatives were brainstormed based on the following boundary conditions.

- Primary tank

$-90,000$ gallons

- Activated stainless steel

-100 gallons of sodium remaining in 24 pockets

- Treat in place (remove only if needed to gain access. Note: change from 2006 baseline assumptions).

- IHX - May be extremely difficult to remove.

- Heaters and shutdown coolers (30' long bayonets - sealed units.)

1.- Rotating plug is hard to access

- Meet RCRA clean requirements and minimize waste streams.

\section{Brainstormed Alternatives}

- Do nothing

- Baseline

- High Temperature Steam

- Epsom Salt

- Alcohol

- Ammonia

- Grout-Cement

- Nitrogen Steam

- WVN Process

- NOX Vapor (all formic acid vapor)

- Remove components mechanically

- Remove sodium only when the primary system is dismantled (for D\&D). Don't go through the clean process now

- Remove and wash the components and place them back in the tank

- Plasma cut or high pressure liquid nitrogen cut openings to access the sodium

- Penetration system - punch the components full of holes

- Final CERCLA disposal at ICDF
- High temperature steam wand with tank heaters. Direct nozzles at the 'pools' of sodium

- Cut every piece out

- Scrape out the tank

- Vacuum distillation

- Recycle the rinse water spray system

- Let the carbonation continue under different conditions

- Disturb the carbonate - ultrasonic device or mechanical stirring / shaking

- Add $\mathrm{NaK}$ to the sodium to melt it

- Burn the residuals - kerosene fire on a pipe

- Reenergize the heaters

- Surgically treat the high radioactive component(s) and establish regulatory platform with the state

- Go to air.

- Fill 1/2 full and boil to make steam 


\section{Baseline Alternative (Permit Option)}

- Fill the tank with water to dissolve the sludge and carbonate and to react the sodium.

- Pull components or treat them in place. These include the IHX (SCMS), rotating plug, shutdown coolers, heaters, and (40) nozzles as the final step to demonstrate sodium activation.

- Pull every cover/nozzle to demonstrate complete sodium reaction. The regulators will want us to show removal of the reactor products remaining in the components.

- Drain the tank.

- Final rinse to collect data.

- Close in place until final disposition path is defined.

Issues:

- It will be very hard to demonstrate complete (100\%) removal of sodium. There will always be some left. This needs to be acknowledged upfront.

- Get agreement from the regulators on a reasonable remaining amount of sodium and show that it is not all in one place. This may have to be demonstrated in some way.

- Sodium may not always react if hidden in parts.

- Radiation levels. Subassemblies were in the reactor for 5 years and out for one year. The cladding measured $10,000 \mathrm{R}$.

- The camera inspection on the primary tank measured 30-50R.

- There is a significant risk to pull components.

- $\mathrm{CO} 2$ replaces the water in the short-term. The tank is open to air in the long-term. 


\section{EVALUATION}

The team identified the functions of the EBR-II primary tank treatment. The three primary functions were identified as neutralize hazard, maximize byproduct removal, and minimize waste.

The evaluation criteria were development based on what the team determined was important to achieving RCRA Clean Closure.

Each brainstormed alternative was discussed to determine how it might be used and how well it addressed the three main functions. Then the team combined and refined the list to produce full alternatives that would meet the RCRA Clean Closure criteria. Finally, the team discussed the Pros and Cons relative to the process and the results. See Appendix A for the initial evaluation table used to narrow-down the list to six viable alternatives, which the INL Water Wash Project Team will investigate and evaluate further.

\subsection{Functions}

- Neutralize hazards

- Maximize byproduct removal

- Minimize waste

- Minimize risk

- Demonstrate no metal contamination

- Remove reactivity

- Locate remaining sodium

- Define waste streams

- Manage expectations with regulator

- Determine final reactor end-state (negotiations with DOE)

- Passivate the primary tank after cleaning

\subsection{Criteria "Wants"}

- Minimize radiation dose

- Minimize hazards

- Minimize waste volume

- Minimize cost

- Regulatory acceptance

- Minimize impacts to future D\&D. (Short-term activities or RCRA closure activities don't impact future D\&D success.)

- Technical maturity

- Ease of demonstrating RCRA clean

- Minimize risk 


\section{ALTERNATIVE EVALUATION RESULTS}

The alternatives below were generated based on the objectives to meet RCRA clean requirements and to minimize waste streams. The team focused on the 90,000 gallon primary tank. Two-thirds of the sodium has been removed and analysis shows approximately 100 gallons of sodium remains in the tank in 24 pockets (various components).

\begin{tabular}{|c|c|c|}
\hline Alternative & Description & Comments \\
\hline $\begin{array}{l}\text { 1. No Further } \\
\text { Action }\end{array}$ & $\begin{array}{l}\text { The hazard is isolated. Two thirds of the } \\
\text { sodium has been treated to date. No byproduct } \\
\text { removal. No waste is generated. }\end{array}$ & $\begin{array}{l}\text { Does not meet RCRA Clean Closure requirements. } \\
\text { Would need approval from regulators that the } \\
\text { activities to date are sufficient. } \\
\text { There is a danger of losing EBR-II expertise the } \\
\text { longer the tank remains untreated. }\end{array}$ \\
\hline $\begin{array}{l}\text { 2. Baseline } \\
\text { (permit) }\end{array}$ & $\begin{array}{l}\text { Completely fill the primary system with water, } \\
\text { Epsom salt, or a caustic solution to dissolve the } \\
\text { sludge and carbonate. Remove components or } \\
\text { treat in place. Pull all components, } \\
\text { covers/nozzles to demonstrate complete sodium } \\
\text { reaction. Drain the tank and do a final rinse to } \\
\text { collect data. Close in place until final } \\
\text { disposition path is defined. }\end{array}$ & $\begin{array}{l}\text { - Activating the sodium will create "pops and bangs" } \\
\text { and should be discussed with regulators. } \\
\text { - It is hard to demonstrate } 100 \% \text { removal of the } \\
\text { sodium. There will always be some left. } \\
\text { - High radiation levels in the tank. } \\
\text { - Removing components produces metal waste streams. }\end{array}$ \\
\hline $\begin{array}{l}\text { 3. Optimized } \\
\text { Approach }\end{array}$ & $\begin{array}{l}\text { Fill the primary tank with water, Epsom salt, or } \\
\text { a caustic solution. Treat critical components in } \\
\text { place to reach as much sodium as possible } \\
\text { without removing them. Perform random } \\
\text { inspection of some components after draining } \\
\text { the tank. Rinse to collect data. }\end{array}$ & $\begin{array}{l}\text { - Less metal waste streams and reduced radiation dose. } \\
\text { - Some tool designs and mockups would be needed to } \\
\text { treat in place. } \\
\text { - Negotiate with the regulators to determine the } \\
\text { acceptable amount of sodium that needs to be treated. }\end{array}$ \\
\hline $\begin{array}{l}\text { 4. Partial Fill / } \\
\text { Steam }\end{array}$ & $\begin{array}{l}\text { Partially fill the tank with water, Epsom Salt or } \\
\text { caustic solution and let it stand for some period } \\
\text { of time to react the sodium. Then heat to } \\
\text { boiling to generate steam in the tank. Remove } \\
\text { or treat applicable components in place. } \\
\text { Remote cutting may be needed. }\end{array}$ & $\begin{array}{l}\text { - } \quad \text { Good residue removal in the nozzles and plugs. } \\
\text { - } \quad \text { Core gas space to expand. } \\
\text { - An analysis is needed to ensure the vessel can } \\
\text { withstand the pressure. }\end{array}$ \\
\hline $\begin{array}{l}\text { 5. High } \\
\text { Temperature } \\
\text { Steam and Inert } \\
\text { Gas (e.g. WVN } \\
\text { process) }\end{array}$ & $\begin{array}{l}\text { Use high temperature steam and inert gas in the } \\
\text { tank. Change the atmosphere in the tank to } \\
\text { nitrogen or argon. Continue steaming until } \\
\text { hydrogen is no longer generated. Rinse the } \\
\text { tank with water. }\end{array}$ & $\begin{array}{l}\text { Minimizes initial water use but will have to neutralize } \\
\text { the solution. } \\
\text { - Reduces the inventory of sodium before rinsing with } \\
\text { water. } \\
\text { May be able to target some pockets of sodium with } \\
\text { steam nozzles. }\end{array}$ \\
\hline $\begin{array}{l}\text { 6. Grout } \\
\text { Primary Tank } \\
\text { using paraffin or } \\
\text { cement. }\end{array}$ & $\begin{array}{l}\text { Pretreat the IHX, the secondary system, and } \\
\text { other components as necessary. Fill the } \\
\text { primary tank with grout. }\end{array}$ & $\begin{array}{l}\text { - This is an interim step prior to final disposition. } \\
\text { - Trout will not treat the IHX or secondary system. } \\
\text { - The water in the grout may neutralize some of the } \\
\text { sodium. } \\
\text { - May require legacy monitoring and performance } \\
\text { - Issessments. } \\
\text { Isolates the hazards, but it becomes a 'dirty' closure. }\end{array}$ \\
\hline
\end{tabular}




\section{SPECIALIST RECOMMENDATIONS}

After the six alternatives were discussed and evaluated, the specialists were asked for their treatment preference for EBR-II.

A. Grouting seems to meet the criteria the best. It should not be too difficult to penetrate components with a basic simple cutting tool, such as liquid nitrogen cutting, etc., and then fill the tank with grout. Unless the tank is dismantled, there is no way to get rid of all the sodium. The grouted primary tank can be handled in the future for final disposition, since there does not seem to a final disposal route identified.

B. Treat the components and pipes in place. Punch holes through the lines and components. Use a directed wand to target the hidden sodium. Then renegotiate with the regulators. Use CO2 or Wet Vapor Nitrogen (WVN) process on the secondary systems while preparing the primary tank. This requires low oversight. These systems will be passivated with little effort.

C. Steam nitrogen wand and drill into components to provide access for the steam. Negotiate with regulators and show that treatment of the high risk components was done in place to target the sodium pockets. The regulators may not care about funding issues. DOE will have to fund the work needed to meet agreements with the state.

D. Optimized approach and negotiate with regulators using the alternatives and actions generated in this meeting. The expertise still exists at the site at this time to get this work done. Regulators can exert pressure on the agencies to provide funding.

E. Optimized approach. A set of tools will be developed from this approach to deal with the secondary systems. This is a good overall approach for the facility.

F. Optimized approach makes final disposition easier. Work with regulators to identify a final disposition path. Interim treatment tools developed will assist in final disposition. Reducing total residual sodium will allow the tank to sit for a period of time, which makes it easier to cut up later. 


\section{PRESENTATION HIGHLIGHTS}

\section{(Power point files of the presentations are available upon request)}

\section{EBR-II History and Initial Cleanup}

Issue: There are pockets that could not drain. We know where they are and how big they are. The reactor was not designed to drain (for end of life or decommissioning.)

In-situ carbonation and water wash was the method to get us to where we are today.

RCRA Waste Treatment Permit. The EBR-II piping system is treated like a large tank. Treat or remove RCRA materials until the tank is considered RCRA clean. The EBR-II permit was issued in 2002 and expires in 2012, but the INL will apply for an extension.

Components were to be removed and treated at the INL Sodium Component Maintenance Shop (SCMS). Solids would be disposed of at a LLW site such as Envirocare or Nevada.

Ethanol wash versus water wash. Ethanol was used to clean components for reuse in the system. Ethanol reacts at a much slower rate. There was a fatality in France by using an alcohol wash, which is flammable. This adds another RCRA hazard.

In 2006, it was estimated that an 8 year project would cost $\$ 28$ million and a 12 year project would cost $\$ 36$ million.

The reactor subsystems are isolated from each other. Treatment could be separate, but it makes sense to clean the systems in a certain order. It is assumed that all subsystems have residual sodium. Systems need to be sampled to verify that the sodium is gone.

Inspections demonstrate to the EPA that progress is being made toward cleanup. We need to show continual progress to be successful in renewing the permit. There are some systems that would provide quick success.

We could also do partial RCRA closure.

Funding issue is the biggest issue facing this project.

The components associated with the primary tank are very hot (radioactive). The pit and primary tank measured $20 \mathrm{R}$. Some of these components could be removed, but it would be better to treat in place. The IHX is very heavy and may be impossible to remove.

Need to know the radiation levels in the tanks and other areas as well as in the activated components that we will be removed. There was not a lot of loose material. Reactor maintenance routinely removed components during normal operations. There is a possibility of high dose by those working on these activities. 
State of Idaho regulations (permit) are clear. The sodium must be reacted and the components removed. A plan is needed that the State of Idaho will accept that leaves the sodium in place.

Video presentation of the inside of the EBR-II primary vessel after the first phase of treatment.

The Run Beyond Cladding Breach (RBCB) program may have resulted in small metal fuel pieces left in the tank. the primary tank sodium was in good shape.

Primary tank analysis identified 24 locations where there could be about 100 gallons of remaining sodium. Surface areas are not of concern. There were 300 gallons of sodium and 200 have been treated.

If the tank was filled, very small pockets of sodium would be encountered. Reactions would occur but would be limited by the small amounts of sodium. There is a bicarbonate layer in the tank which would slow down the instantaneous reactions.

There are two major issues.

1. As the tank is filled, the water will reach the grid plate overflowing into the high pressure plenum, which is the first big pocket.

2. The very top of the reactor cover, which is slightly open, has many pockets and nozzles (in the gallons of range), but the water may not reach these areas.

There are two large tanks at MFC connected with $1 / 2$ mile long sodium transfer line. Treatment was to cut up the transfer line and clean with water. Instead, it was disconnected from the buildings. The ends were capped and moist $\mathrm{CO} 2$ was pumped into the pipes. The hydrogen was monitored over a 6 week period until all the sodium had reacted in the pipe. Then it was filled with water and drained. A final rinse was done for RCRA verification. The line awaits D\&D.

\section{Dounreay Overview}

The off site sodium test facility is currently in mothballs. It can handle up to 1 ton of sodium and is designed to $50 \mathrm{R}$. Sodium hydroxide was used to clean the sodium, which is not nearly as vigorous as water.

Pay attention to residual sodium in the secondary circuits - gas phase areas due to complex geometries.

Their regulators agreed with low concentration WVN. They held regular meetings with their Regulators.

\section{Fermi 1 Overview}

They have shipped 15,000 gallons of wash water to Utah for grouting. Another 30,000 gallons will be shipped soon. It costs about $\$ 177,000$ to ship and grout 10,000 gallons. 


\section{Pacific Northwest National Laboratory (PNNL)}

The FFTF is a $400 \mathrm{MWt}$ reactor. The spent nuclear fuel is in storage. There are three shipments remaining of unirradiated fuel to the INL.

The drained bulk sodium is stored in four big tanks and will be sent to the glassification plant, which should be online in 2019. (245,000 gal of sodium in 4 tanks)

Regulators said to keep it in safe condition and not to treat it. The contract will be rebid contract in 2015. We assume entombment for the reactor vessel, which includes the sodium. Treatment options have not been considered. 


\section{ACRONYMS}

BEA Battelle Energy Alliance, LLC

CERCLA Comprehensive Environmental Response, Compensation, and Liability Act

D\&D Decontaminate and Decommission

DOE US Department of Energy

EBR-II Experimental Breeder Reactor

EM DOE Office of Environmental Management

EPA Environmental Protection Agency

FFTF $\quad$ Fast Flux Test Facility

HEPA High Efficiency Particulate Air (Filter)

ICDF Idaho CERCLA Disposal Facility

ICP Idaho Cleanup Project

IHX Intermediate Heat Exchanger

INL Idaho National Laboratory

INTEC Idaho Nuclear Technology and Engineering Center (formerly ICPP)

IWTU Integrated Waste Treatment Unit

LLW Low Level Waste

MFC Materials and Fuels Complex

MWt Mega Watt Thermal

$\mathrm{NaK} \quad$ Sodium-Potassium Alloy (Reactor Coolant)

NE DOE Office of Nuclear Energy

NOX Nitrous Oxide

RBCB Run Beyond Cladding Breach

RCRA Resource Conservation and Recovery Act

RTC Reactor Technology Complex (formerly TRA)

SCMS Sodium Components Maintenance Shop

SME Subject Matter Expert

SRNL Savannah River National Lab

UK AEA United Kingdom Atomic Energy Agency

VE Value Engineering

WVN Wet Vapor Nitrogen 


\section{ATTENDEES}

\begin{tabular}{|c|c|c|c|c|}
\hline \multicolumn{2}{|c|}{ Name } & Phone & E-Mail & Organization \\
\hline \multicolumn{5}{|c|}{$\begin{array}{l}\text { EXPERT PANEL } \\
\end{array}$} \\
\hline Bill & Church & $509-376-9113$ & william_r_bill_church@rl.gov & FFTF, Hanford \\
\hline Steve & Lien & $301-903-0114$ & stephen.lien@em.doe.gov & DOE-HQ \\
\hline Leonard & Mason & $\begin{array}{l}+44(0) 1847 \\
802087\end{array}$ & leonard.mason@ukaea.org.uk & UK AEA Dounreay \\
\hline Dick & Meservey & $208-526-1834$ & richard.meservey@inl.gov & $\begin{array}{l}\text { INL, Env Eng \& } \\
\text { Tech }\end{array}$ \\
\hline Steve & Sherman & $803-725-8725$ & steven.sherman@srnl.doe.gov & $\begin{array}{l}\text { SRNL, (formerly } \\
\text { EBR-II) }\end{array}$ \\
\hline Danny & Swindle & $\begin{array}{l}734-586-1798 \\
\text { (c) } 734-915-5857\end{array}$ & swindled@dteenergy.com & $\begin{array}{l}\text { Fermi, Detroit } \\
\text { Edison }\end{array}$ \\
\hline Peter & Thompson & $\begin{array}{c}+44(0) 1847 \\
831497 \\
\end{array}$ & $\begin{array}{l}\text { peter.thompson@ethanconsultancy.co.u } \\
\text { k }\end{array}$ & $\begin{array}{l}\text { Ethan Consultancy } \\
\text { Ltd }\end{array}$ \\
\hline \multicolumn{5}{|c|}{ INL WASH WATER PROJECT TEAM } \\
\hline Rick & Demmer & $208-533-4277$ & rick.demmer@inl.gov & INL \\
\hline John & Heintzelman & $208-526-3034$ & john.heintzelman@inl.gov & INL \\
\hline Collin & Knight & $208-533-7707$ & collin.knight@inl.gov & INL \\
\hline Leah & Squires & $208-533-8049$ & leah.squires@inl.gov & INL \\
\hline \multicolumn{5}{|c|}{ PROJECT / MEETING SUPPORT } \\
\hline Chad & Bohannon & $724-272-9194$ & chad@creativeengineers.com & $\begin{array}{l}\text { Contractor - Sodium } \\
\text { Treatment }\end{array}$ \\
\hline Lori & Braase & $208-526-7763$ & lori.braase@inl.gov & $\begin{array}{l}\text { INL, Systems } \\
\text { Engineering }\end{array}$ \\
\hline Tim & Carlson & $208-526-9324$ & timothy.carlson@inl.gov & INL \\
\hline Dan & Crisp & $\begin{array}{l}208-533-0210 \\
\text { (c) } 208-520-4895\end{array}$ & daniel.crisp@icp.doe.gov & ICP \\
\hline Loren & Flatten & $208-533-7680$ & loren.flatten@inl.gov & INL \\
\hline Dave & Gianotto & $208-526-8529$ & david.gianotto@icp.doe.gov & ICP \\
\hline Roy & Grant & $208-526-9559$ & roy.grant@,inl.gov & INL \\
\hline Dave & Nickelson & $208-526-9061$ & dave.nickelson@icp.doe.gov & ICP \\
\hline Jay & Roach & $208-526-4974$ & jay.roach@inl.gov & INL \\
\hline Maxine & Rubick & $208-533-7396$ & 1.rubick@inl.gov & INL \\
\hline Paul J. & Smith & $208-533-7921$ & paul.smith@inl.gov & INL \\
\hline Jim & Thalgott & $208-533-7624$ & james.thalgott@inl.gov & INL \\
\hline Tom & Zahn & $208-533-7217$ & thomas.zahn@inl.gov & INL \\
\hline
\end{tabular}




\section{APPENDIX A}

This table represents the initial evaluation of the brainstormed list of alternatives to clean the EBR-Primary System. The team first discussed each alternative to determine how it might be used and how well it addressed the three main functions: neutralize hazard, maximize byproduct removal, and minimize waste. Then the team combined and refined the list to produce full alternatives that would meet the RCRA Clean Closure criteria. Finally, the team discussed the Pros and Cons relative to the process and the results.

Six full alternatives were developed, which the INL Water Wash Project Team will investigate and evaluate further.

The current state of the primary system contains a one inch layer of sodium carbonate. Two thirds of the sodium has been treated and a final water wash was done. "Byproduct" refers to treatment residuals, such as dissolved carbonate and hydroxide.

\begin{tabular}{|c|c|c|c|c|c|c|c|}
\hline & Alternatives & $\begin{array}{c}\text { Neutralize } \\
\text { Hazard }\end{array}$ & $\begin{array}{c}\text { Maximize } \\
\text { Byproduct } \\
\text { Removal }\end{array}$ & $\begin{array}{l}\text { Minimize } \\
\text { Waste }\end{array}$ & Pro & Con & Comment \\
\hline 1 & $\begin{array}{l}\text { No further } \\
\text { action. }\end{array}$ & $\begin{array}{l}\text { Hazard is } \\
\text { isolated. } \\
\text { Treated } 2 / 3 \\
\text { of sodium. } \\
\text { Radiation } \\
\text { will } \\
\text { eventually } \\
\text { decay. }\end{array}$ & $\begin{array}{l}\text { No } \\
\text { byproduct } \\
\text { removal. }\end{array}$ & No Waste & $\begin{array}{l}\text { No further } \\
\text { expense. } \\
\text { Min } \\
\text { monitoring. } \\
\text { Cost benefit } \\
\text { approach may } \\
\text { show this is } \\
\text { the right way } \\
\text { to go. } \\
\text { Achievable } \\
\text { option. }\end{array}$ & $\begin{array}{l}\text { Approval } \\
\text { from state } \\
\text { that what } \\
\text { was done } \\
\text { was } \\
\text { sufficient. } \\
\text { Violates } \\
\text { permit. } \\
\text { Leaving it } \\
\text { for next } \\
\text { project. } \\
\text { More } \\
\text { expensive in } \\
\text { the long run. } \\
\text { Does not } \\
\text { meet our } \\
\text { RCRA clean } \\
\text { closure } \\
\text { objective. } \\
\text { Danger of } \\
\text { losing } \\
\text { expertise the } \\
\text { longer we } \\
\text { wait. }\end{array}$ & $\begin{array}{l}\text { This is an } \\
\text { alternative that } \\
\text { we feel we } \\
\text { would not be } \\
\text { successful } \\
\text { with the } \\
\text { regulators. }\end{array}$ \\
\hline 2 & $\begin{array}{l}\text { Baseline } \\
\text { 1.A. Water } \\
\text { 2.B. Epsom } \\
\text { Salt } \\
\text { 3.C. Caustic } \\
\text { Solution }\end{array}$ & & $\begin{array}{l}\text { Remove all } \\
\text { the water. } \\
\text { Everything } \\
\text { dissolved in } \\
\text { solution. } \\
\text { Reflood and } \\
\text { check for }\end{array}$ & & $\begin{array}{l}\text { Epsom salt. } \\
\text { Take credit } \\
\text { for the } \\
\text { carbonate in } \\
\text { the tank now. } \\
\text { Safer - more } \\
\text { control - }\end{array}$ & $\begin{array}{l}\text { Epsom salt is } \\
\text { still in } \\
\text { development } \\
\text { stage. } \\
\text { Higher waste } \\
\text { generation } \\
\text { going to }\end{array}$ & $\begin{array}{l}\text { Extensive } \\
\text { inspections, } \\
\text { removal of } \\
\text { byproducts. } \\
\text { Would have to } \\
\text { install } \\
\text { circulating }\end{array}$ \\
\hline
\end{tabular}




\begin{tabular}{|c|c|c|c|c|c|c|c|}
\hline & Alternatives & $\begin{array}{l}\text { Neutralize } \\
\text { Hazard }\end{array}$ & $\begin{array}{c}\text { Maximize } \\
\text { Byproduct } \\
\text { Removal } \\
\end{array}$ & $\begin{array}{l}\text { Minimize } \\
\text { Waste }\end{array}$ & Pro & Con & Comment \\
\hline & & & $\begin{array}{l}\text { heavy } \\
\text { metals. Use } \\
\text { a wand to } \\
\text { demonstrate } \\
\text { compliance. } \\
\text { Good } \\
\text { option to } \\
\text { max } \\
\text { byproduct } \\
\text { removal. }\end{array}$ & & $\begin{array}{l}\text { slows down } \\
\text { the reaction. }\end{array}$ & $\begin{array}{l}\text { evaporation. } \\
\text { Increase } \\
\text { waste } \\
\text { volume due } \\
\text { to low } \\
\text { solubility. } \\
\text { Safer than } \\
\text { water alone. } \\
\text { Complicates } \\
\text { water } \\
\text { disposal if } \\
\text { filters are } \\
\text { needed. } \\
\text { Adds to filter } \\
\text { loading. }\end{array}$ & $\begin{array}{l}\text { pumps or } \\
\text { some method } \\
\text { to circulate the } \\
\text { water. } \\
\text { Need to do } \\
\text { analysis and } \\
\text { build a safety } \\
\text { case about } \\
\text { activating the } \\
\text { sodium. } \\
\text { Activating the } \\
\text { sodium will } \\
\text { create "pops } \\
\text { and bangs." } \\
\text { This has to be } \\
\text { discussed with } \\
\text { the regulator. } \\
\text { Need to know } \\
\text { what pressure } \\
\text { pulse that the } \\
\text { vessel can } \\
\text { withstand. } \\
\text { Look in } \\
\text { original STD. } \\
\text { Idea: install } \\
\text { microphones } \\
\text { outside of the } \\
\text { tank to listen } \\
\text { to the noises. }\end{array}$ \\
\hline & & & & & $\begin{array}{l}\text { Caustic. } \\
\text { Not adding a } \\
\text { different } \\
\text { species to the } \\
\text { solution. } \\
\text { Slows down } \\
\text { the reaction. } \\
\text { Initial feed } \\
\text { only - not the } \\
\text { total } 90 \\
\text { gallons. }\end{array}$ & $\begin{array}{l}\text { Caustic. } \\
\text { Prepare } \\
\text { before } \\
\text { adding to the } \\
\text { tank - get to } \\
\text { the right pH. } \\
\text { Would have } \\
\text { to be } \\
\text { neutralized. } \\
\text { Handling and } \\
\text { safety issues. } \\
\text { Corrosion. } \\
\text { Hydroxide- } \\
\text { stainless may } \\
\text { be } \\
\text { susceptible to } \\
\text { leaching } \\
\text { (Chromium } \\
\text { component } \\
\text { that is not } \\
\text { desirable). }\end{array}$ & $\begin{array}{l}\text { Could buy } \\
\text { plastic tanks } \\
\text { to prepare } \\
\text { solution. } \\
\text { Salt or caustic. } \\
\text { May slow } \\
\text { down reaction } \\
\text { too much. } \\
\text { You may not } \\
\text { get the desired } \\
\text { reaction. }\end{array}$ \\
\hline 3 & Optimized & Flooding & Same as & Treat & Less metal & Tool designs & Permit \\
\hline
\end{tabular}




\begin{tabular}{|c|c|c|c|c|c|c|c|}
\hline & Alternatives & $\begin{array}{c}\text { Neutralize } \\
\text { Hazard }\end{array}$ & $\begin{array}{c}\text { Maximize } \\
\text { Byproduct } \\
\text { Removal } \\
\end{array}$ & $\begin{array}{l}\text { Minimize } \\
\text { Waste }\end{array}$ & Pro & Con & Comment \\
\hline & $\begin{array}{l}\text { Approach. } \\
\text { Fill primary } \\
\text { tank with water } \\
\text { and show state } \\
\text { that we have } \\
\text { reacted X\% of } \\
\text { the sodium. } \\
\text { A. Water } \\
\text { 1.B. Epsom } \\
\text { Salt } \\
\text { 2.C. Caustic }\end{array}$ & only. & baseline. & $\begin{array}{l}\text { critical } \\
\text { components } \\
\text { in place; } \\
\text { majority of } \\
\text { sodium. } \\
\text { Random } \\
\text { inspection } \\
\text { of some } \\
\text { components } \\
\text { after fill } \\
\text { and drain to } \\
\text { characterize } \\
\text { the problem } \\
\text { for further } \\
\text { action. }\end{array}$ & $\begin{array}{l}\text { waste } \\
\text { streams. } \\
\text { Reduced } \\
\text { radiation } \\
\text { dose. } \\
\text { Reduced } \\
\text { industrial \& } \\
\text { airborne } \\
\text { contamination } \\
\text { hazards. }\end{array}$ & $\begin{array}{l}\text { needed to } \\
\text { treat in place. } \\
\text { Some remote } \\
\text { development } \\
\text { - out of tank } \\
\text { testing- } \\
\text { mockups. } \\
\text { More } \\
\text { difficult to } \\
\text { do visual } \\
\text { inspections. }\end{array}$ & $\begin{array}{l}\text { resolution - } \\
\text { all byproduct } \\
\text { removal } \\
\text { verified by } \\
\text { visual } \\
\text { inspection. } \\
\text { Possible to } \\
\text { verify by other } \\
\text { means. }\end{array}$ \\
\hline 4 & $\begin{array}{l}\text { Partially } \\
\text { fill/steam } \\
\text { Partially fill the } \\
\text { tank with water } \\
\text { and let it sit for } \\
\text { a while. Then } \\
\text { heat it to boiling } \\
\text { to generate } \\
\text { steam. } \\
\text { 1.A. Water } \\
\text { 2.B. Epsom } \\
\text { Salt } \\
\text { 3.C. Caustic }\end{array}$ & $\begin{array}{l}\text { Treat } \\
\text { applicable } \\
\text { components } \\
\text { in place. } \\
\text { Remote } \\
\text { cutting } \\
\text { options. } \\
\text { Need to } \\
\text { have a cost } \\
\text { benefit } \\
\text { analysis of } \\
\text { removal or } \\
\text { treat in } \\
\text { place. (all } \\
\text { alt) Need } \\
\text { the facility } \\
\text { to handle } \\
\text { the } \\
\text { component } \\
\text { cleaning and } \\
\text { packaging } \\
\text { and } \\
\text { disposal) }\end{array}$ & & $\begin{array}{l}30,000 \\
\text { gals. Less } \\
\text { than } \\
\text { Baseline } \\
\text { and } \\
\text { Optimized. }\end{array}$ & $\begin{array}{l}\text { Good residue } \\
\text { removal in } \\
\text { nozzles and } \\
\text { plugs. } \\
\text { More gas } \\
\text { space to } \\
\text { expand. }\end{array}$ & $\begin{array}{l}\text { Stored } \\
\text { energy from } \\
\text { the steam. } \\
\text { Structural } \\
\text { integrity } \\
\text { assessment } \\
\text { (safety case). } \\
\text { (Need to be } \\
\text { done for all } \\
\text { alternatives). } \\
\text { Less mass to } \\
\text { absorb the } \\
\text { sodium } \\
\text { reaction. } \\
\text { Changes to } \\
\text { the } \\
\text { ventilation } \\
\text { system. } \\
\text { Scrubber - } \\
\text { all } \\
\text { alternatives. }\end{array}$ & $\begin{array}{l}\text { If something } \\
\text { happens you } \\
\text { can't just stop } \\
\text { the flow of } \\
\text { water since } \\
\text { you are } \\
\text { generating } \\
\text { steam. Can't } \\
\text { stop the } \\
\text { reaction. Melt } \\
\text { the sodium. } \\
\text { Get the big } \\
\text { pockets in the } \\
\text { reactor core } \\
\text { with the fill. } \\
\text { Could also be } \\
\text { used with } \\
\text { directed } \\
\text { nozzles (\#5) } \\
\text { Steam comes } \\
\text { from the } \\
\text { boiling water. } \\
\text { Analysis } \\
\text { needed to } \\
\text { ensure the } \\
\text { vessel can } \\
\text { stand the } \\
\text { pressure. }\end{array}$ \\
\hline 5 & $\begin{array}{l}\text { High } \\
\text { Temperature } \\
\text { Steam and inert } \\
\text { gas. (WBN) }\end{array}$ & $\begin{array}{l}\text { Carried the } \\
\mathrm{CO} 2 \\
\text { process as } \\
\text { far as we } \\
\text { can. Now } \\
\text { change the } \\
\text { atmosphere. } \\
\text { Produces } \\
\text { concentrated }\end{array}$ & $\begin{array}{l}\text { Rinsing step } \\
\text { needed. }\end{array}$ & $\begin{array}{l}\text { Minimizes } \\
\text { initial water } \\
\text { use. } \\
\text { May have } \\
\text { more waste } \\
\text { because the } \\
\text { solution } \\
\text { will have to } \\
\text { be }\end{array}$ & $\begin{array}{l}\text { Reduce the } \\
\text { inventory of } \\
\text { sodium } \\
\text { before rinsing } \\
\text { with water. } \\
\text { Ability to } \\
\text { target pockets } \\
\text { of sodium. }\end{array}$ & $\begin{array}{l}\text { May have } \\
\text { dilute the } \\
\text { caustic } \\
\text { reduced. } \\
\text { May form } \\
\text { solid caustic } \\
\text { if you keep } \\
\text { steaming. }\end{array}$ & $\begin{array}{l}\text { Controlled } \\
\text { steam } \\
\text { reaction. Low } \\
\text { inventory of } \\
\text { water in the } \\
\text { tank. Not } \\
\text { directed } \\
\text { steam. Above } \\
100 \text { Degrees }\end{array}$ \\
\hline
\end{tabular}




\begin{tabular}{|c|c|c|c|c|c|c|c|}
\hline & Alternatives & $\begin{array}{l}\text { Neutralize } \\
\text { Hazard }\end{array}$ & $\begin{array}{c}\text { Maximize } \\
\text { Byproduct } \\
\text { Removal } \\
\end{array}$ & $\begin{array}{l}\text { Minimize } \\
\text { Waste }\end{array}$ & Pro & Con & Comment \\
\hline & & $\begin{array}{l}\text { liquor in the } \\
\text { bottom of } \\
\text { the tank. } \\
\text { Continue } \\
\text { steaming } \\
\text { until no } \\
\text { more } \\
\text { hydrogen is } \\
\text { generated. } \\
\text { Rinse with } \\
\text { water. } \\
\text { Need to } \\
\text { choose a } \\
\text { temperature } \\
\text { that } \\
\text { provides the } \\
\text { benefit. }\end{array}$ & & neutralized. & & & $\begin{array}{l}\text { C. Change the } \\
\text { atmosphere to } \\
\text { nitrogen or } \\
\text { argon. Large } \\
\text { pockets of } \\
\text { sodium on the } \\
\text { reactor core } \\
\text { cover and } \\
\text { upper areas of } \\
\text { reactor. They } \\
\text { don't have a } \\
\text { large amount } \\
\text { of carbon on } \\
\text { them. May be } \\
\text { hard to get the } \\
\text { steam to these } \\
\text { areas. }\end{array}$ \\
\hline & Epsom Salt & & & & & & $\begin{array}{l}\text { Additive in } \\
\text { the fill method } \\
\text { water. To } \\
\text { reduce } \\
\text { reactions. } \\
\text { Needs some } \\
\text { development. }\end{array}$ \\
\hline & Aleohel & & & & & & $\begin{array}{l}\text { Increases } \\
\text { hazard. Some } \\
\text { development }\end{array}$ \\
\hline & Ammonia & & & $\begin{array}{l}\text { Creates } \\
\text { another } \\
\text { waste } \\
\text { stream }\end{array}$ & & & $\begin{array}{l}\text { Increases } \\
\text { hazards. } \\
\text { Some } \\
\text { Development. }\end{array}$ \\
\hline 6. & $\begin{array}{l}\text { Cement - Grout } \\
\text { Primary Tank } \\
\text { Paraffin, cement } \\
\text { A. Some } \\
\text { pretreatment } \\
\text { B. No } \\
\text { pretreatment }\end{array}$ & $\begin{array}{l}\text { Water in } \\
\text { grout may } \\
\text { neutralize } \\
\text { some of the } \\
\text { sodium. } \\
\text { Would not } \\
\text { treat the } \\
\text { IHX or the } \\
\text { secondary } \\
\text { system } \\
\text { Interim step } \\
\text { prior to final } \\
\text { disposition. }\end{array}$ & & $\begin{array}{l}\text { Cement } \\
\text { waste. } \\
\text { No liquid } \\
\text { waste. } \\
\text { May have } \\
\text { some } \\
\text { unused } \\
\text { grout. } \\
\text { Lowest } \\
\text { waste } \\
\text { volume } \\
\text { option. }\end{array}$ & $\begin{array}{l}\text { Isolates the } \\
\text { hazard. } \\
\text { EBR-II is a } \\
\text { National } \\
\text { Monument } \\
\text { and may not } \\
\text { want to move } \\
\text { it. } \\
\text { Could } \\
\text { provide a } \\
\text { final } \\
\text { disposition } \\
\text { path. } \\
\text { May be the } \\
\text { lowest cost } \\
\text { option. } \\
\text { Minimal or } \\
\text { no worker } \\
\text { exposure. } \\
\text { Mature }\end{array}$ & $\begin{array}{l}\text { May not be } \\
\text { readily } \\
\text { acceptable by } \\
\text { the state. } \\
\text { May have to } \\
\text { have final } \\
\text { disposition } \\
\text { agreement } \\
\text { with DOE \& } \\
\text { state. } \\
\text { Potential } \\
\text { hazard with } \\
\text { Nak and } \\
\text { organics. It } \\
\text { is sealed it } \\
\text { the } \\
\text { components. } \\
\text { Could impact } \\
\text { D\&D options } \\
\text { down the }\end{array}$ & $\begin{array}{l}\text { Could } \\
\text { deactivate } \\
\text { sodium with } \\
\text { grout if State } \\
\text { approves } \\
\text { doing this in } \\
\text { place. Legacy } \\
\text { monitoring } \\
\text { may be } \\
\text { required. } \\
\text { More difficult } \\
\text { to move. } \\
\text { Radiological } \\
\text { issues. Would } \\
\text { ICDF take } \\
\text { reactive grout. } \\
\text { Water in grout } \\
\text { would react } \\
\text { with the } \\
\text { sodium. }\end{array}$ \\
\hline
\end{tabular}




\begin{tabular}{|c|c|c|c|c|c|c|c|}
\hline & Alternatives & $\begin{array}{l}\text { Neutralize } \\
\text { Hazard }\end{array}$ & $\begin{array}{c}\text { Maximize } \\
\text { Byproduct } \\
\text { Removal }\end{array}$ & $\begin{array}{l}\text { Minimize } \\
\text { Waste }\end{array}$ & Pro & Con & Comment \\
\hline & & & & & $\begin{array}{l}\text { technology. } \\
\text { Accepted in } \\
\text { DOE and } \\
\text { regulators. } \\
\text { Could pick up } \\
\text { the vessel and } \\
\text { move it or cut } \\
\text { it for final } \\
\text { disposal. }\end{array}$ & $\begin{array}{l}\text { road. } \\
\text { Hazards left- } \\
\text { dirty closure. } \\
\text { Would have } \\
\text { to negotiate } \\
\text { with state on } \\
\text { surveillance } \\
\text { requirements. } \\
\text { Triggers } \\
\text { performance } \\
\text { assessments. } \\
\text { No overlap } \\
\text { with cleaning } \\
\text { secondary } \\
\text { systems. The } \\
\text { secondary } \\
\text { systems can't } \\
\text { be grouted. }\end{array}$ & $\begin{array}{l}\text { Paraffin grout } \\
\text { would not } \\
\text { impact future } \\
\text { D\&D. If you } \\
\text { pretreat, then } \\
\text { why grout. }\end{array}$ \\
\hline & Nitrogen Steam & & & & & & \\
\hline 7. & WVN Process & $\begin{array}{l}\text { Similar to } \\
\text { steam. }\end{array}$ & $\begin{array}{l}\text { Additional } \\
\text { step to } \\
\text { remove } \\
\text { byproduct. }\end{array}$ & & & & $\begin{array}{l}\text { Liquid } \\
\text { product. Have } \\
\text { to render } \\
\text { down the dry } \\
\text { product. }\end{array}$ \\
\hline 8. & $\begin{array}{l}\text { NOX Vaper } \\
\text { (all formic acid } \\
\text { vapor) }\end{array}$ & $\begin{array}{l}\text { Breaks } \\
\text { down the } \\
\text { bicarbonate. } \\
\text { Could be } \\
\text { used in } \\
\text { conjunction } \\
\text { with other } \\
\text { with other } \\
\text { alternatives. }\end{array}$ & & & & & $\begin{array}{l}\text { Industrial use } \\
\text { chemical. } \\
\text { Would have to } \\
\text { ensure that the } \\
\text { HEPA filters } \\
\text { would handle } \\
\text { this and } \\
\text { ensure it is } \\
\text { covered under } \\
\text { permits. May } \\
\text { dissolve } \\
\text { corrosion } \\
\text { product. } \\
\text { Introduce Co2 } \\
\text { into system. }\end{array}$ \\
\hline & $\begin{array}{l}\text { Mechanically } \\
\text { remove (by } \\
\text { hand or } \\
\text { remotely) } \\
\text { Applies to } \\
\text { several } \\
\text { alternatives. }\end{array}$ & $\begin{array}{l}\text { Method to } \\
\text { access the } \\
\text { sodium }\end{array}$ & & & & & $\begin{array}{l}\text { Radiation } \\
\text { levels. Would } \\
\text { still need } \\
\text { another } \\
\text { facility to } \\
\text { remove the } \\
\text { sodium. } \\
\text { Remove the } \\
\text { minimum } \\
\text { needed to } \\
\text { provide } \\
\text { access. }\end{array}$ \\
\hline
\end{tabular}




\begin{tabular}{|c|c|c|c|c|c|c|c|}
\hline & Alternatives & $\begin{array}{c}\text { Neutralize } \\
\text { Hazard }\end{array}$ & $\begin{array}{c}\text { Maximize } \\
\text { Byproduct } \\
\text { Removal } \\
\end{array}$ & $\begin{array}{l}\text { Minimize } \\
\text { Waste }\end{array}$ & Pro & Con & Comment \\
\hline & $\begin{array}{l}\text { Pon't ge } \\
\text { through clean } \\
\text { process. } \\
\text { Remove } \mathrm{Na} \\
\text { when it is } \\
\text { dismantled. }\end{array}$ & & & & & & $\begin{array}{l}\text { Not legal } \\
\text { under the } \\
\text { current permit } \\
\text { to pass on } \\
\text { deactivation. } \\
\text { Outside of } \\
\text { scope of } \\
\text { RCRA clean } \\
\text { closure. High } \\
\text { exposure and } \\
\text { risk }\end{array}$ \\
\hline & $\begin{array}{l}\text { Remove, wash } \\
\text { components, } \\
\text { and place back } \\
\text { into the tank. }\end{array}$ & & & & & & $\begin{array}{l}\text { Radiation is } \\
\text { high. Facility } \\
\text { needed to } \\
\text { remove } \\
\text { sodium. No } \\
\text { path for } \\
\text { disposal for } \\
\text { this. } \\
\text { Transportation } \\
\text { and } \\
\text { acceptance as } \\
\text { sodium LLW. }\end{array}$ \\
\hline & $\begin{array}{l}\text { Plasma cut } \\
\text { epenings to } \\
\text { access Na. } \\
\text { High pressure } \\
\text { liquid nitrogen } \\
\text { cutting. }\end{array}$ & & & & & & $\begin{array}{l}\text { Works in a } \\
\text { non-oxygen } \\
\text { environment. } \\
\text { Enabling } \\
\text { technique. Do } \\
\text { in-situ. } \\
\text { Remote } \\
\text { cutting to get } \\
\text { access. } \\
\text { Supports the } \\
\text { mechanical } \\
\text { removal ideas. }\end{array}$ \\
\hline & $\begin{array}{l}\text { Penetration } \\
\text { system - punch } \\
\text { full of holes. }\end{array}$ & & & & & & $\begin{array}{l}\text { Access } \\
\text { method. }\end{array}$ \\
\hline & $\begin{array}{l}\text { Dispese at } \\
\text { ICDF Finat }\end{array}$ & & & & & & Out of scope. \\
\hline 9. & $\begin{array}{l}\text { Steam wand } \\
\text { with tank } \\
\text { heaters. High } \\
\text { temp. Direct } \\
\text { nozzles at poels } \\
\text { of sodium }\end{array}$ & & & & & & $\begin{array}{l}\text { Pools of } \\
\text { sodium are not } \\
\text { readily } \\
\text { accessible. } \\
\text { Surgically } \\
\text { treat the } \\
\text { sodium. } \\
\text { Multiple } \\
\text { injection } \\
\text { points. Pipe }\end{array}$ \\
\hline
\end{tabular}




\begin{tabular}{|c|c|c|c|c|c|c|c|}
\hline & Alternatives & $\begin{array}{l}\text { Neutralize } \\
\text { Hazard }\end{array}$ & $\begin{array}{c}\text { Maximize } \\
\text { Byproduct } \\
\text { Removal }\end{array}$ & $\begin{array}{l}\text { Minimize } \\
\text { Waste }\end{array}$ & Pro & Con & Comment \\
\hline & & & & & & & $\begin{array}{l}\text { steam ahead } \\
\text { of time. } \\
\text { Maintain } \\
\text { control. }\end{array}$ \\
\hline & $\begin{array}{l}\text { Cut every piece } \\
\text { out }\end{array}$ & & & & & & $\begin{array}{l}\text { See issues } \\
\text { above. }\end{array}$ \\
\hline & $\begin{array}{l}\text { Serape out the } \\
\text { tank }\end{array}$ & & & & & & $\begin{array}{l}\text { Generates } \\
\text { additional } \\
\text { metal } \\
\text { contamination. } \\
\text { May be hard } \\
\text { to get the } \\
\text { mechanical } \\
\text { tool into the } \\
\text { tank. }\end{array}$ \\
\hline & $\begin{array}{l}\text { Vacumm } \\
\text { distillation } \\
\text { (MEDE) }\end{array}$ & & & & & & $\begin{array}{l}\text { Primary tank } \\
\text { may collapse. } \\
\text { Pressure issue. } \\
\text { Not feasible } \\
\text { due to } \\
\text { carbonate. } \\
\text { May be viable } \\
\text { for other } \\
\text { vessels. } \\
\text { Consider for } \\
\text { IHX. }\end{array}$ \\
\hline & $\begin{array}{l}\text { Recycle the } \\
\text { rinse water } \\
\text { spray system }\end{array}$ & & & $\begin{array}{l}\text { Way to min } \\
\text { waste but } \\
\text { not a stand } \\
\text { alone } \\
\text { option. }\end{array}$ & & & \\
\hline 10. & $\begin{array}{l}\text { Let the } \\
\text { earbonation run } \\
\text { continuous - } \\
\text { under different } \\
\text { conditions }\end{array}$ & $\begin{array}{l}\text { Approach to } \\
\text { go after } \\
\text { more } \\
\text { sodium. } \\
\text { Interim } \\
\text { measure } \\
\text { Will get the } \\
\text { sodium out } \\
\text { over a very } \\
\text { long period } \\
\text { of time. }\end{array}$ & $\begin{array}{l}\text { Increases } \\
\text { byproduct. } \\
\text { Reduces } \\
\text { sodium. }\end{array}$ & & & $\begin{array}{l}\text { Long term } \\
\text { option. }\end{array}$ & $\begin{array}{l}\text { Minimal } \\
\text { surveillance. } \\
\text { May want to } \\
\text { heat the water } \\
\text { tank. } \\
\text { Maintain } \\
\text { current state } \\
\text { activity. Runs } \\
\text { at minimal } \\
\text { rate. May } \\
\text { have to } \\
\text { change permit } \\
\text { language. } \\
\text { May be able to } \\
\text { switch from } \\
\text { CO2 to wet } \\
\text { vapor } \\
\text { nitrogen. }\end{array}$ \\
\hline
\end{tabular}




\begin{tabular}{|c|c|c|c|c|c|c|}
\hline Alternatives & $\begin{array}{c}\text { Neutralize } \\
\text { Hazard }\end{array}$ & $\begin{array}{c}\text { Maximize } \\
\text { Byproduct } \\
\text { Removal }\end{array}$ & $\begin{array}{l}\text { Minimize } \\
\text { Waste }\end{array}$ & Pro & Con & Comment \\
\hline & & & & & & $\begin{array}{l}\text { Change } \\
\text { conditions. } \\
\text { Expansion } \\
\text { differences } \\
\text { with temp } \\
\text { changes. }\end{array}$ \\
\hline $\begin{array}{l}\text { Disturb the } \\
\text { earbenate (e.g. } \\
\text { tlltrasonic } \\
\text { device, } \\
\text { meehanical } \\
\text { stirring/shaking }\end{array}$ & & & & & & $\begin{array}{l}\text { Pressure } \\
\text { containment } \\
\text { limits on } \\
\text { devices. } \\
\text { Initial step to } \\
\text { other } \\
\text { alternatives. }\end{array}$ \\
\hline $\begin{array}{l}\text { Add Nak to } \\
\text { soditm to melt } \\
\text { it }\end{array}$ & & & & & & $\begin{array}{l}\text { Liquid Nak to } \\
\text { sodium and } \\
\text { agitate it to } \\
\text { heat it. }\end{array}$ \\
\hline $\begin{array}{l}\text { Burn the } \\
\text { residuals } \\
\text { (kerosene fire) }\end{array}$ & & & & & & \\
\hline $\begin{array}{l}\text { Reenergize } \\
\text { heaters }\end{array}$ & & & & & & $\begin{array}{l}\text { Another tool } \\
\text { to melt the } \\
\text { sodium. }\end{array}$ \\
\hline $\begin{array}{l}\text { Surgically treat } \\
\text { high radiation } \\
\text { eomponent(s) } \\
\text { and establish } \\
\text { regultatory } \\
\text { platform with } \\
\text { state }\end{array}$ & & & & & & $\begin{array}{l}\text { Focus on the } \\
3-4 \text { systems } \\
\text { that have the } \\
\text { most sodium. } \\
\text { Management } \\
\text { decision. } \\
\text { Plasma arc, } \\
\text { etc. } \\
\text { Wands. This } \\
\text { is the strategic } \\
\text { direction. }\end{array}$ \\
\hline Go to air & & & & & & $\begin{array}{l}\text { Version of do } \\
\text { nothing. } \\
\text { Weathering } \\
\text { option. } \\
\text { Sodium } \\
\text { exposed to air } \\
\text { will react with } \\
\text { oxygen. Long } \\
\text { term } \\
\text { approach. }\end{array}$ \\
\hline & & & & & & \\
\hline
\end{tabular}

